\title{
Background Review Paper on Total Fat, Fatty Acid Intake and Cancers
}

\author{
Mariette Gerber \\ Expert French Agency for Food Safety and Security, French Nutrition Sty, Pdt, Montpellier, France
}

\section{Introduction}

This background document was commissioned by the Food and Agriculture Organization (FAO) and the World Health Organization (WHO).

In 1993, an expert consultation meeting organized by the FAO and the WHO was held in Rome. During this consultation, the requirements for fats and fatty acids (FA) were reviewed and discussed at length. The report of this consultation was published in 1994 by the FAO [FAO/WHO, 1994].

In this report, the chapter on cancer was rather brief, covering generalities and only 2 specific cancers: breast and colon. The concluding remarks reflected the difficulties in resolving contradictions between animal and human studies, between the results of ecological and analytical epidemiology, and the absence of data on specific FA. The experts noticed the relationship between cancers and obesity, and drew attention to energy balance and the necessity of appropriate physical exercise.

Since 1994, results from several different types of studies (case-control and prospective studies based on questionnaires or nutritional markers, and intervention trials) have been reported. Design and methodology has improved, especially food composition tables, which allowed the gathering of data on specific FA. Several working groups prepared reports in France [CNERNA-CNRS, 1996; AFSSA, 2003], the United Kingdom [COMA, 1998] and an international group [WCFR/AICR, 1997, 2007].
This report has benefited from these advances, and aims to present new evidence with a potential impact upon dietary recommendations.

In this background review paper, colorectal, prostate, breast, endometrial and ovary cancers will be covered successively, and the effect of total fat will be evaluated for each. The effect of specific FA (saturated, monounsaturated, n-6 and n-3 polyunsaturated, trans FA) will be evaluated on colorectal, prostate and breast cancer. In the latter, the effects of combined inadequate intakes of n-6 and n-3 polyunsaturated FA and of polyunsaturated FA and antioxidants have been shown in some studies, and will also be discussed.

\section{Method}

The WCRF/AICR database was updated with studies published after 2006, although some older studies were later included. When the recent studies contradicted the WCRF/AICR conclusions, a re-evaluation of the systematic literature review in the WCRF/AICR report was judged necessary. As specific FA were not covered by the WCRF/AICR report, because none of them was found to have sufficient evidence to indicate a probable or convincing relationship to any form of cancer, the French Food Safety Agency (AFSSA) report in 2003 provided the baseline data. The final additions to the database were online reports obtained in August 2008.

\section{KARGER \\ Fax +4161306 1234 \\ E-Mail karger@karger.ch}

www.karger.com
(C) 2009 S. Karger AG, Basel and FAO

$0250-6807 / 09 / 0553-0140 \$ 26.00 / 0$

Accessible online at:

www.karger.com/anm
Mariette Gerber

Expert French Agency for Food Safety and Security, French Nutrition Sty, Pdt 7, Rue Bourrelly

FR-34000 Montpellier (France) 
Criteria of validity have been applied to the new studies covered here, such as sample size, ascertainment of disease diagnosis, quality of exposure assessment (questionnaire/interview characteristics, number of items, food groups, and relevance of biological markers), quality of statistics (adjustment for confounding factors). The exclusion of studies was always justified.

The evaluation of evidence indicating a relationship between cancers and nutritional factors was founded on the mosaic (or portfolio) approach to take into consideration the complexity of the relationship: phases of carcinogenesis, unavoidable residual confounding of food and food patterns when looking at a nutrient, metabolic pathways involved (e.g. hormonal, immunological). Therefore, all types of studies were reviewed critically, with their strengths and limitations carefully evaluated. Biological plausibility and mechanistic hypotheses were included in the assessment. Hill's criteria [Hill, 1965] were broadly used to qualify the causal inference. While consistency of all studies represented the optimal criteria of judgment, the level of heterogeneity mostly had to be evaluated as explainable (a probable or possible level of evidence can be set) or not (insufficient criteria). Hence, dietary FA requirements were proposed whenever criteria of judgment were sufficient.

\section{Colorectal Cancer}

Colorectal cancer (CRC) is the third most common cancer in the world, with around 1 million cases. The incidence is greatest in high-income countries, but is rising with industrialization and urbanization in emergent countries and even in low-income countries. Food and nutrition have an important relationship with income, industrialization and urbanization, and may form the basis of a preventative strategy. Since body fatness and abdominal fatness increase CRC risk [WCRF/AICR, 2007], fat intake was among the first factors investigated in epidemiological studies, after fiber intake.

\section{Total Fat}

The epidemiological studies reviewed by WCRF/AICR [2007] showed inconsistent results (with a positive association more often found in case-control studies than in cohorts, which was most of the time negated after energy adjustment) and no association in the Women Health Initiative's (WHI) randomized controlled trial [Prentice et al., 2006]. Therefore, the report did not comment upon total fat intake, but formed conclusions based on limited but suggestive evidence of the relationship between CRC and animal fat.

Since the report, 4 case-control studies and 2 cohorts have reported on total fat and CRC (table 1A, B). The 2 Japanese case-control studies showed no association [Wakai et al., 2006; Kimura et al., 2007], the Scottish one [Theodoratou et al., 2007] showed a positive association of total fat with CRC that disappeared after energy adjustment, and the Canadian one [Hu et al., 2007] reported a positive association, but the questionnaire used was insufficient (70 items) and the adjustment was for total energy (not residual method). None of the 2 cohorts [Oba et al., 2006; Weijenberg et al., 2007] showed an association. A recent cohort study analyzed the relationship to CRC not by individual nutrients, but by dietary patterns [Flood et al., 2008]. However, it is relevant to our task, since a low-fat food pattern was individualized. Among the participants $(492,382)$ from the National Institutes of Health's AARP Diet and Health Study cohort, 2,151 cases were ascertained in men and 959 in women. A low-fat diet was associated with a decreased risk of CRC (relative risk: $0.82,95 \%$ CI: $0.72-0.94$, p for trend: 0.001 in men; relative risk: $0.87,95 \% \mathrm{CI}: 0.71-1.07$, $\mathrm{p}$ for trend: 0.06 in women).

With regard to biological plausibility and mechanisms, a hypothesis for a specific risk related to lipids was proposed based on experimental work: lipids increase the secretion of bile acids in the colon that can be metabolized by bacterial flora to mutagenic deoxycholic acids, as shown in rodents. Another indication is the participation of lipids in the excess of energy intake [Tang et al., 1996] shown in the seminal experiments on caloric restriction [Tannenbaum, 1942]. The strong correlation between energy and total fat intake in high-income countries, where most of the studies have been conducted [Astorg et al., 2004], explains the disappearance of the association between total fat and CRC after adjustment for energy. That means that fat cannot be considered as a risk factor for CRC beyond its contribution to energy intake, which is likely to be high in Western countries. Reciprocally, in a country where energy is more strongly correlated with carbohydrates, relative risk is $<1$ for lipids and $>1$ for carbohydrates, as shown (although non-significantly) in Wakai et al. [2006] and Kimura et al. [2007].

If total fat intake has an impact upon CRC risk, it is in proportion to its contribution to caloric intake and/or to energy-dense food pattern. The WCRF [2007] recognizes that there is limited but suggestive evidence that foods containing animal fat increase CRC risk. 


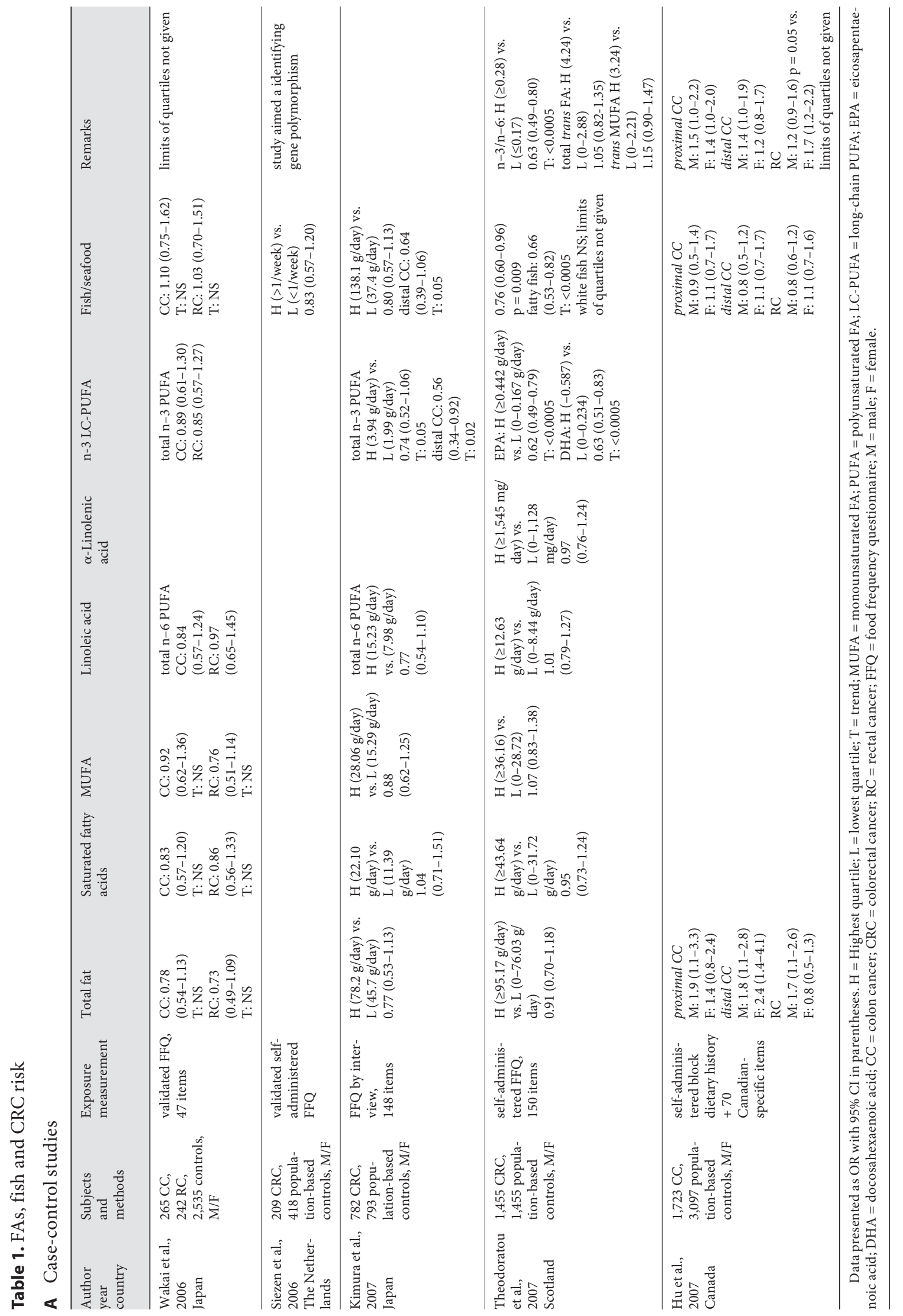




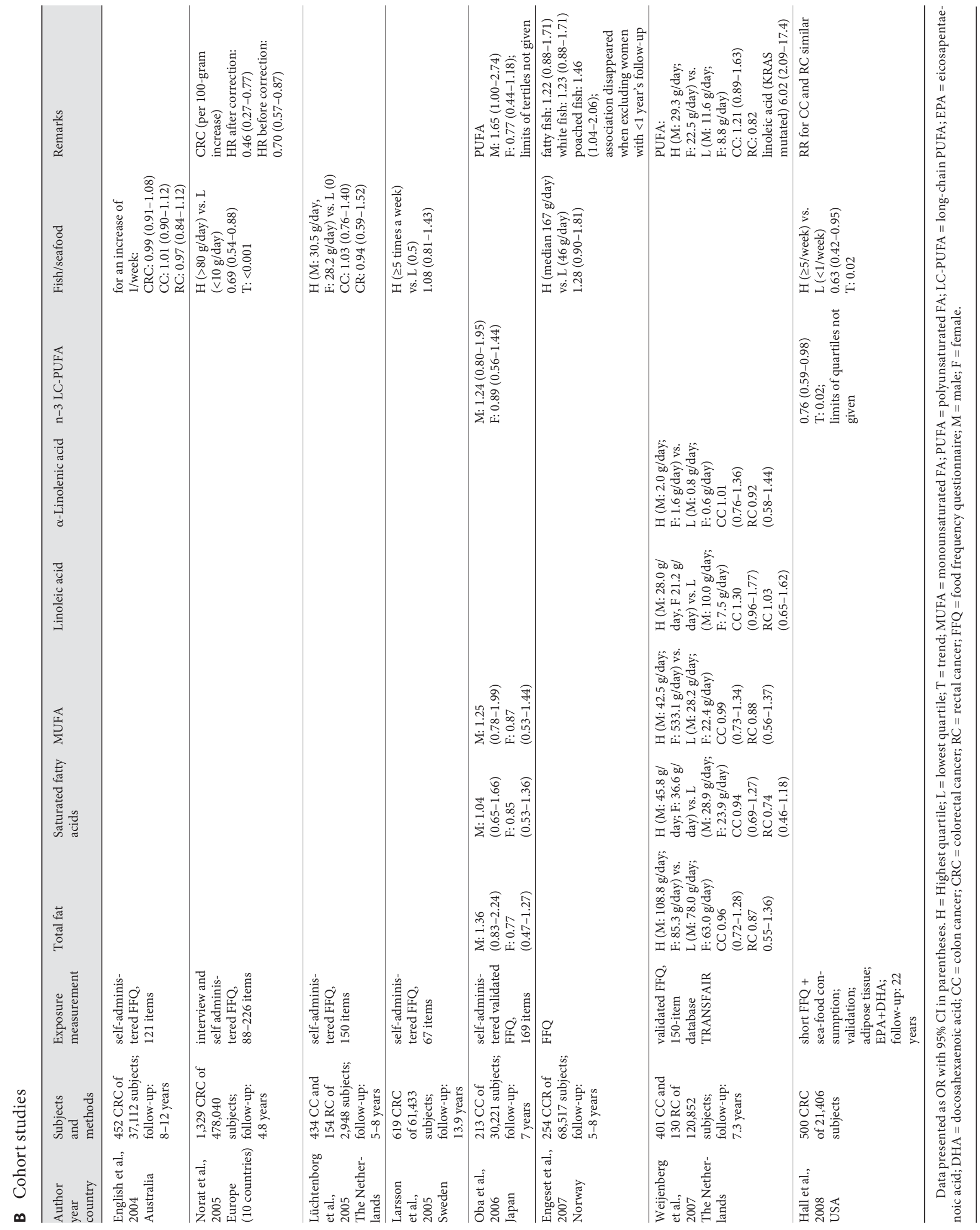




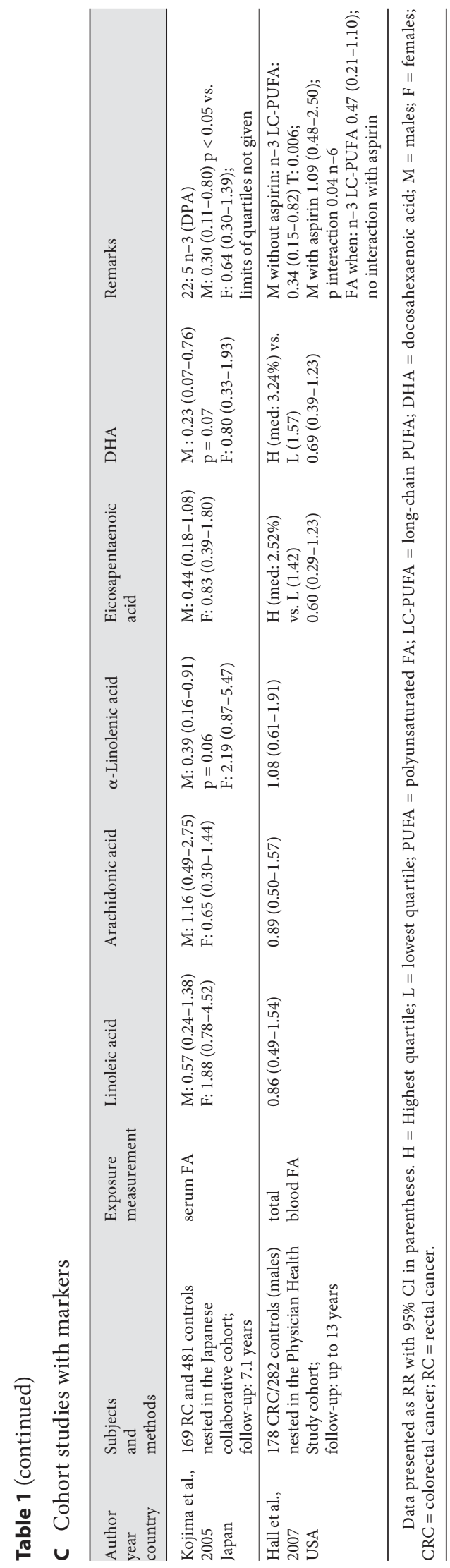

\section{Saturated and Monounsaturated FA}

These FA are comparable to total fat with regard to their association with rectal cancer, as described in table $1 \mathrm{~A}$ and $\mathrm{B}$. In a complementary study on gene-nutrient interaction, Theodoratou et al. [2008] showed that the subjects carrying the variant APC 1822 and consuming a low amount of monounsaturated FA (MUFA) had a reduced risk of CRC, with a significant interaction $(0.52$, 95\% CI: 0.30-0.92, T: 0.017, p for interaction: 0.02). However, since red meat intake presented the same interaction but more strongly, this might be a result of residual confounding, since in a non-Mediterranean diet, meat is the highest contributor of MUFA. Thus, the conclusion is similar to the one given for total fat.

Several ecological studies [Stoneham et al., 2000; Siari et al., 2002] have suggested that olive oil is associated with a risk reduction for CRC; this has also been reported in case-control studies [Rouillier et al., 2005; Galeone et al., 2007]. This effect is not related to oleic acid, since this is not observed when MUFA is provided by meat, but possibly to the unsaponifiable components of olive oil, and/or more likely to the Mediterranean diet accompanying olive oil consumption (see 'Breast Cancer' for more information).

\section{n-6 FA: Linoleic Acid}

There is no coverage of specific acids in the WCRF/ AICR report [2007] due to insufficient data. As noted in the AFSSA report [2003], an absence of association has been shown in most of the studies on the relationship between linoleic acid (LA) and CRC. The more recent casecontrol studies using questionnaires to measure exposure [Wakai et al., 2006; Kimura et al., 2007; Theodoratou et al., 2007], as well as the cohort studies using either questionnaires [Weijenberg et al., 2007] or blood markers [Kojima et al., 2005; Hall et al., 2007], support the absence of relationship.

\section{n-3 FA: Linolenic Acid}

The data reported for LA apply for linolenic acid (ALA), with the exception of a cohort study based on serum FA measure [Kojima et al., 2005] showing a significantly decreased risk in men and a non-significant increased risk in women (table 1C).

The heterogeneity of the findings cannot be explained, and neither biological plausibility nor experimental models support a modifying effect of ALA on CRC risk.

\section{n-3 FA: Long-Chain Polyunsaturated FA}

In all populations, the major contributor to the body of n-3 long-chain polyunsaturated FA (LC-PUFA), eico- 
sapentaenoic acid (EPA) and docosahexaenoic acid (DHA) is seafood. Therefore, the relationship of CRC with fish and/or seafood intake, which are the measures used most often, is considered in this paragraph.

The WCRF/AICR report [2007] noted that there is limited evidence that eating fish protects against CRC. Since the report, 4 case-control studies [Wakai et al., 2006; Siezen et al., 2006; Kimura et al., 2007; Hu et al., 2007] have reported no association, whereas 1 report [Theodoratou et al., 2007] has shown a risk reduction (table 1A). In the same period of time, the results of 6 cohort studies were published [English et al., 2004; Norat et al., 2005; Larsson et al., 2005; Lüchtenborg et al., 2005; Engeset et al., 2007; Hall et al., 2008]. Only 2 reports [Norat et al., 2005; Hall et al., 2008] showed a significant risk reduction (table 1B). A meta-analysis, including the data from 14 studies but not from Hall et al. [2008], showed a borderline significant risk reduction in CRC incidence (0.88, 95\% CI: 0.78-1.00 [Geelen et al., 2007]).

With regard to n-3 LC-PUFA, it appeared that in 2007 (WCRF/AICR report), as well as in 2003 (AFSSA report), there was not sufficient data to form any conclusions. Two case-control studies (table 1A) [Kimura et al., 2007; Theodoratou et al., 2007] and 2 cohort studies reported on the relationship of n-3 LC-PUFA intake measured by questionnaire (table 1B) [Oba et al., 2006; Hall et al., 2008], with 2 showing a significant risk reduction [Theodoratou et al., 2007; Hall et al., 2008]. This effect is reinforced in subjects carrying the APC 1822 gene variant [Theodoratou et al., 2008]. In addition, 2 cohort studies [Kojima et al., 2005; Hall et al., 2007] using biomarkers of n-3 LC-PUFA intake, showed a risk reduction in CRC in the quartile with the highest percentage of $n-3$ LC-PUFA in the blood, significant in Kojima et al. [2005], and for the subjects not taking aspirin, with a significant interaction test [Hall et al., 2007] (table 1C). This observation alludes to a possible mechanism of n-3 LC-PUFA.

In animal models, it has constantly been observed that an n-3 LC-PUFA-rich diet inhibits colon tumorigenesis compared with LA [Reddy, 1984] and with a lipid-rich Western diet [Rao et al., 2001].

Two hypotheses support the biological plausibility of the risk-reducing effect of n-3 LC-PUFA: (1) the anti-inflammatory effect and inhibition of COX 2 enzyme (see 'Effects of Fat and Fatty Acid Intake on Inflammatory and Immune Responses: A Critical Review' by Galli and Calder, this issue); (2) the anti-apoptotic effect shown in animal models [Chang et al., 1998].

Fish intake is not equivalent to n-3 LC-PUFA consumption, given that fish contains other nutrients of in- terest in cancer protection, e.g. vitamin D and selenium. However, there is a correlation between blood levels of n-3 LC-PUFA and fish intake [Gerber et al., 2000; Hall et al., 2008]. In addition, since meat appears to be a convincing risk factor for $\mathrm{CRC}$, replacing meat by fish might confound the risk reduction observed for high intakes of fish. Nevertheless, the recent studies strengthen the probability of a causal relationship between fish intake and CRC. Moreover, 2 recent cohort studies using biological markers suggest a favorable effect of n-3 LC-PUFA on CRC risk. Experimental models and biological plausibility support these observations.

Thus, it can be said that fish intake probably decreases CRC risk, and that limited data are suggestive of a causal relationship between n-3 LC-PUFA intake and CRC risk reduction.

\section{Trans Fatty Acids}

The WCRF/AICR [2007] panel concluded that any effects of trans FA specifically on the risk of any cancer is not known. This conclusion does not have to be modified since only 1 large case-control study showed a non-significant increase in CRC risk for people with the highest intake of trans MUFA [Theodoratou et al., 2007] (table 1A).

\section{Prostate Cancer}

Prostate cancer (PC) is the second most common cancer in men, accounting for around $12 \%$ of all new cases of cancers in the world. Screening for prostate-specific antigen (PSA) is in part responsible for its high reported incidence in high-income countries. PC is generally recognized as a hormone-dependent cancer, and is known to vary with ethnic characteristics.

\section{Total Fat}

The WCRF/AICR [2007] panel concluded that the evidence was so limited with regard to the relationship between total fat and PC that no firm conclusion could be made. This was even truer for specific FA.

Since then, 3 case-control studies [Bidoli et al., 2005; Hedelin et al., 2007; Liu et al., 2007], and 3 cohort studies [Park et al., 2007; Neuhouser et al., 2007; Wallström et al., 2007] have reported no association with total fat (table $2 \mathrm{~A}$, B). Thus, the conclusion does not require modification.

\section{Saturated FA}

The studies quoted previously did not find any association between PC and saturated FA (SFA). A recent 

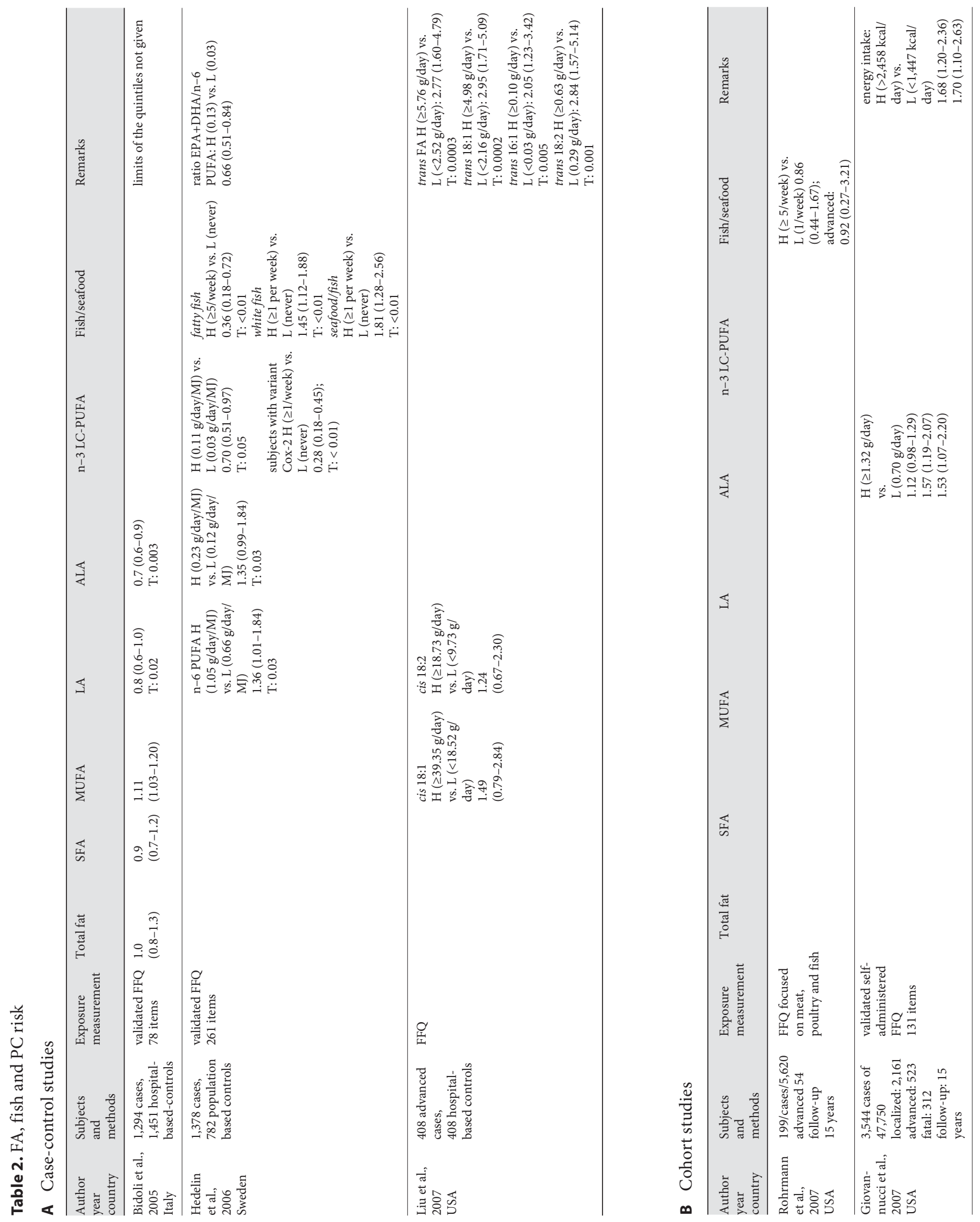


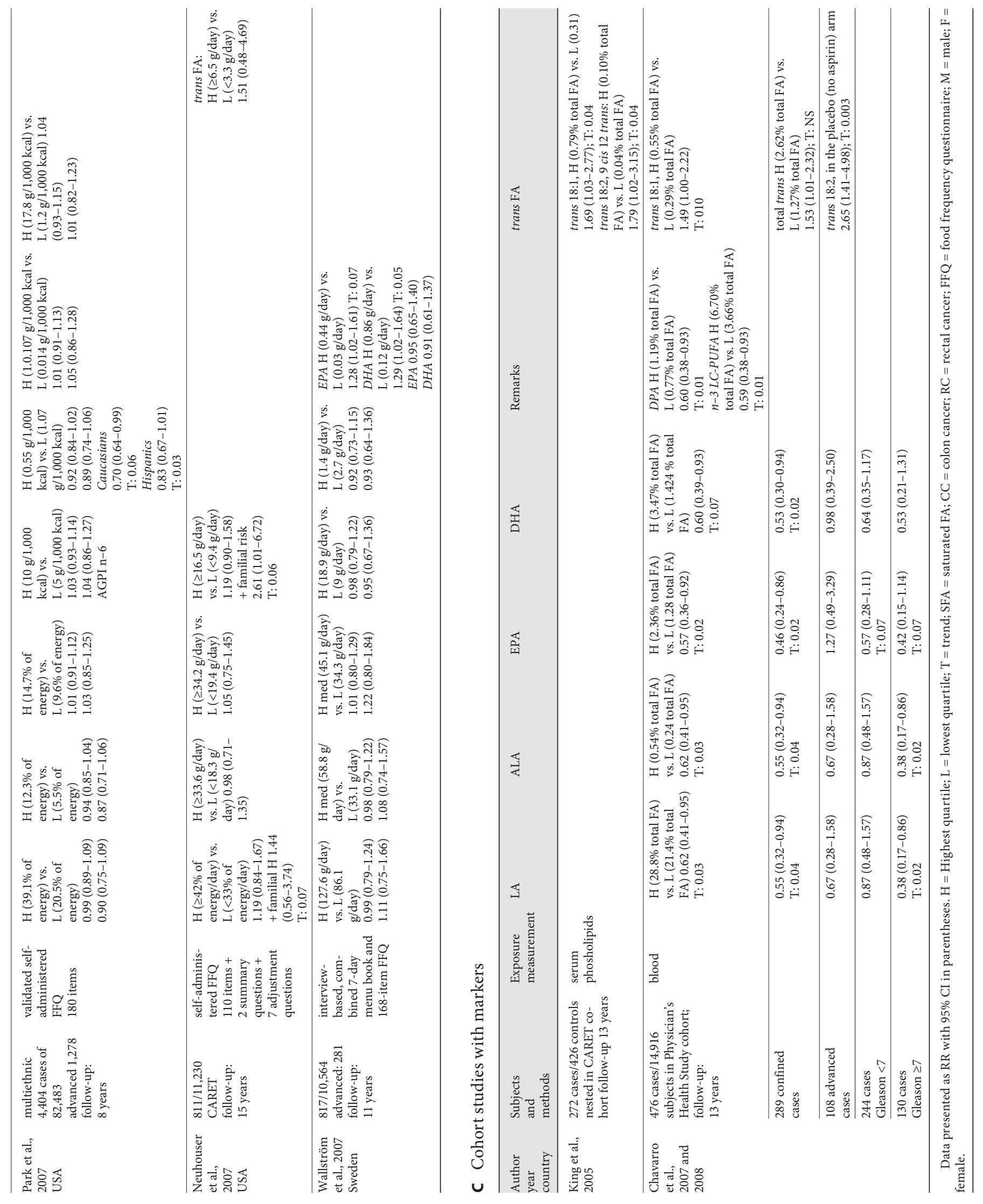


study investigating the relationship between PC and dairy products [Kurahashi et al., 2008], reported a borderline significant risk of high SFA acid intake, and a significant increased risk for high intake of myristic and palmitic acids (table 2B). In addition, Strom et al. [2008] reported that among 390 patients presenting with organconfined PC after prostatectomy, men who consumed high-SFA diets were more likely to experience increasing PSA levels ( $p=0.006)$, the biochemical failure that signals progression. These men had significantly shorter biochemical failure-free survival than men with low-SFA diets (26.6 vs. 44.7 months, respectively, $\mathrm{p}=0.002$ ). The questionnaire was the validated Block questionnaire, completed with specific south-western dishes (180 items). Low SFA was characterized by $31.0 \%$ of total energy intake (TEI) as fat and $9.9 \%$ as SFA, and the high-SFA diet by 39.6 and $14.1 \%$, respectively. The model with energyadjusted saturated fat explained more variance in the data and was better at predicting outcome compared to the one with TEI. However, the data are too limited to support any conclusion.

\section{Monounsaturated FA}

Among the studies quoted above, 1 case-control study [Bidoli et al., 2005] reported a modest but significant increase in risk for high intake of MUFA (table 2A). Nevertheless, the data are too limited to support any conclusion.

\section{n-6 FA: Linoleic Acid}

The 3 case-control studies [Bidoli et al., 2005; Hedelin et al., 2007; Liu et al., 2007] reported conflicting results, and 3 cohort studies [Neuhouser et al., 2007; Park et al., 2007; Wallström et al., 2007] reported no association (table 1A, B). There is probably no relationship between LA and PC.

\section{n-3 FA: Linolenic Acid}

The 3 case-control studies [Bidoli et al., 2005; Hedelin et al., 2007; Liu et al., 2007] and 5 cohort studies [Giovannucci et al., 2007; Neuhouser et al., 2007; Park et al., 2007; Wallström et al., 2007; Chavarro et al., 2007, 2008] reported conflicting results. Neither biological plausibility nor experimental models support a deleterious effect of ALA. Therefore, it is likely that the risk associated with high intake in some studies results from residual confounding. Cattle being fed with soy, rich in ALA, could be responsible for the residual confounding; thus, confounding the limited but suggestive risk associated with processed meat, milk and dairy products.

\section{n-3 FA Long-Chain Polyunsaturated FA}

In all populations, the major contributor of n-3 LCPUFA, EPA and DHA is seafood. Therefore, relationship of PC to fish intake, which is the measure most often used, is considered here.

A case-control study from Sweden reported a reduction in risk for the highest intake of fatty fish, but an increased risk for white fish and seafood [Hedelin et al., 2006] (table 2A). Two cohort studies reported no association [Rohrmann et al., 2007; Park et al., 2007] (table 2B).

With regard to specific n-3 LC-PUFA, 1 case-control study reported on the association of PC with n-3 LCPUFA, and indicated a reduced risk; the subjects carrying a mutation in the gene COX2 were even better protected by the intake of EPA + DHA than the subjects carrying the most common gene [Hedelin et al., 2007]. On the contrary, the highest intake of EPA + DHA increased the risk in the overall sample, but had no effect on the risk in advanced cases in the Malmö Diet and Cancer Cohort [Wallström et al., 2007]. A prospective study with biomarker assessment of the exposure [Chavarro et al., 2007] observed a significant risk reduction in all cases and localized cases of PC for a high percentage of n-3 LC-PUFA in blood, but not for advanced PC.

Animal models showed an inhibition of prostate carcinogenesis by a n-3 LC-PUFA-enriched diet [Karmali et al., 1987].

With regard to biological plausibility, the same mechanisms as those for CRC are proposed for PC. The results of the study by Hedelin et al. [2007] on the COX2 gene polymorphism are in line with the proposed Cox 2 inhibition.

The evidence of a protective effect of $n-3$ LC-PUFA against PC is limited, and heterogeneity of results might be considered in the light of possible environmental fish contaminants.

\section{Trans Fatty Acids}

The WCRF/AICR [2007] panel concluded that any effect of trans FA specifically on the risk of cancer is not known. A case-control study using a questionnaire [Liu et al., 2007] and 2 case-control studies nested in cohorts (CARET [King et al., 2005] and Physician Health Study [Chavarro et al., 2008]) using biomarkers for the assessment of exposure showed an increased risk of PC for the highest exposure to trans 16:1, 18:1 and 18:2 (table 2A) [Liu et al., 2007] and 18:1 11 trans and 18:2 9 cis 12 trans (table 2C) [King et al., 2005] and trans 18:1 and total trans FA (table 2C) [Chavarro et al., 2008]. One cohort study did not show any effect [Neuhouser et al., 2007] (table 2B). 
In the study by Liu et al. [2007], this effect was modified by the RNASEL R462Q polymorphism (p interaction $<0.01$ ). The QQ/RQ genotype is associated with the proapoptotic activity of the RNAse $\mathrm{L}$, and the variant results in a deficient activity. Among men with this genotype, the association between total trans FA, trans 18:1, trans 18:2 intake and PC was substantially stronger: ORs of higher quartiles equal to 4.80 (2.29-10.08), 5.11 (2.45$10.66)$ and 3.64 (1.65-8.08), respectively. In the study of Chavarro et al. [2008], the effect is strong with a linear dose-dependent effect in subjects of the placebo arm with regard to trans 18:2 and absent in the aspirin-treated subjects, suggesting an interference with the COX enzymes' pathway. These last 2 cohort studies in addition to the case-control study strongly suggested an increased risk of PC related to trans FA intake. The trans FA could act on PC risk in an opposite way than that suggested for $n-3$ LC-PUFA in the study of Hedelin et al. [2007]. Even if more studies are necessary, these observations, although limited in number, are suggestive of a direction towards a risk associated with trans FA intake.

\section{Breast Cancer}

Breast cancer (BC) is the most common cancer in women worldwide. More than 1 million cases were recorded in 2002. It is also the leading cause of death from cancer in women, and especially in women below 65 years of age.

Hormone metabolism is the preponderant influential factor for BC: high estradiol either from endogenous (high synthesis and/or altered regulation of binding proteins) or exogenous sources is the major risk factor. Inversely, all situations characterized by low estradiol synthesis are associated with a reduced risk (e.g. anovulatory cycle, lactation). Thus, $\mathrm{BC}$ risk factors vary with changes in hormonal status throughout women's lives, before and after menopause, pregnancy and lactation. Furthermore, hormonal status influences the proliferation/differentiation of the mammary epithelium throughout life, and these different epithelial states are characterized by a different vulnerability to endogenous and exogenous carcinogens.

Most of the lifestyle factors modify BC risk through their effect on hormone metabolism as well as other factors related to industrialization and urbanization. These factors encompass societal changes, such as women's sexual liberation and entry into the world of work, resulting in late ages at births, low parity and low frequency of lac-

Total Fat, Fatty Acids Intake and Cancers tation; they also encompass possible environmental factors, such as endocrine disruptors. Altogether, these lifestyle, societal and possible environmental factors participate in the high incidence of BCin high-income countries, and in the rapidly increasing incidence in emergent and low-income countries.

\section{Total Fat}

The relationship of total fat with $\mathrm{BC}$ has been a matter of debate for a long time. Several arguments have fueled the discussion: (1) the inconsistency of results from casecontrol and prospective studies; (2) the statistical techniques to alleviate the confounding between energy and fat, which are strongly correlated; (3) that body fatness, which might be related to fat intake (see 'The Relationship between Dietary Fat and Fatty Acid Intake and Body Weight, Diabetes and the Metabolic Syndrome' by Melanson et al., this issue), is probably protective in pre-menopausal (PRM) women and definately deleterious in postmenopausal women (POM).

Two hypotheses have been proposed to solve the later paradoxical observation: one is the protective effect of frequent anovulatory menstrual cycles in PRM women, [WCRF/AICR, 2007]; the rationale of the other is based on the known influence of estrogen on the expression of the gene of lipoprotein lipase in adipose tissue. As a consequence, hyperestrogenic women are rather lean, and hypoestrogenic ones, rather overweight; thus, obesity in PRM women would reflect a hypoestrogenemia and a lower risk for BC [Gerber, 1997a]. For POM women, it is generally accepted that body fatness is a risk factor through extragonadal estrogen synthesis. Thus, the role of nutrition-related factors of body fatness appears less preponderant in PRM women than in POM women, where at-risk hormone profile levels might be modified by nutrition [Berrino et al., 2001; Kaaks et al., 2003].

Among the nutrients, the relationship of total fat was judged to be suggestive, but limited, by the WCRF/AICR [2007]. However, the meta-analysis of 22 case-control studies presented in the support resource of the systematic literature review shows a modest but significant increased risk $(\mathrm{OR}=1.03, \mathrm{CI}: 1.02-1.04$, for an increment of $20 \mathrm{~g} /$ day of total fat), and that of 7 case-control studies showed an overall OR of 1.11 (CI: 1.03-1.06). In addition, the WHI study [Prentice et al., 2006] showed a risk reduction for BC with a low-fat diet, which is borderline significant (fig. 1). In addition, several pieces of evidence seem to confirm this effect: (1) It was stronger in women with the highest fat intake at baseline. (2) Hormone concentrations decreased in the experimental group, and 
Fig. 1. Kaplan-Meier estimates of the cumulative hazard for invasive BC [Prentice et al., 2006]. HR: 0.91 (95\% CI: 0.83-1.01).

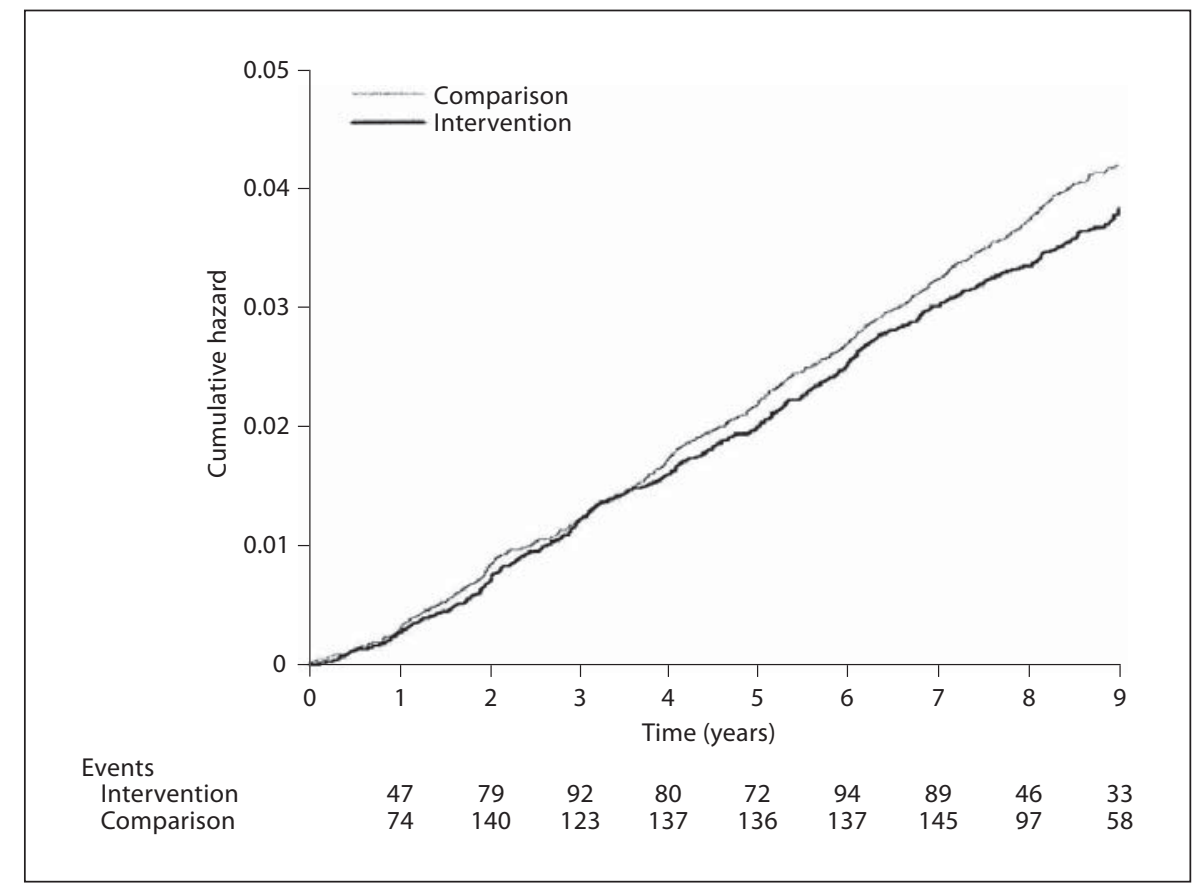

were not modified in the control group. This change in hormone concentration is observed in women treated by anti-aromatase, and adipose tissue aromatase is believed to be responsible for extragonadal hormone synthesis. (3) SHBG (sex-hormone-binding globulin) decreased in the experimental group, and was not modified in the control group. Decreased SHBG releases free testosterone and to a lesser extent estradiol, which are risk factors for BC. (4) Among the 17 baseline demographic variables, medical history and health behavior tested using an unweighted proportional hazards model stratified by age and randomization group, the test for interaction was significant for elevated hypertension and leukocyte count (evoking possible inflammation), both of which are present in metabolic syndrome. The observations 2 , 3 and 4 meet biological plausibility (synthesis of extragonadal estrogens) and proposed mechanisms (role of each of the components of the metabolic syndrome in $\mathrm{BC}$ risk). However, weight loss by itself may explain these observations, and can be observed under any caloric restriction.

More recently, 1 case-control study [Wang et al., 2008] and 1 cohort study [Thiébaut et al., 2007] reported an increased risk with high intake of total fat, whereas another cohort study [Löf et al., 2007] showed mostly negative results (table 3A, B).
Overall, the 'limited and suggestive' relationship - as qualified by the WCRF [2007] - is very likely based on the fat contribution to energy and energy-dense food intake as shown by Schulz et al. [2008] in the PotsdamEPIC cohort study (HR: 2.00; 95\% CI: 1.30-3.09 for highfat food pattern) without any specific effect of total fat. The heterogeneity might come from studies conducted in populations where carbohydrates are the major contributor to energy-dense foods with low-physical activity or subjects are at risk of metabolic syndrome [Lajous et al., 2008]. Total fat has to be kept at a reasonable level, especially fat-dense foods.

Finally, several studies [Borugian et al., 2004'ㄹ ; McEligot et al., 2006 ${ }^{2}$ ] and 1 intervention assay [Cheblowski et al., 2006] showed better survival in BC patients with low intake of total fat. The study by Cheblowski et al. [2006] randomized for $60 \%$ of the controls and $40 \%$ of the cases, followed 975 early BC patients and 1,462 controls for a median duration of 5 years. The recommended diet aimed at $15 \%$ of TEI for the experimental group with intensive counseling, contrary to the control group. The TEI in the

\footnotetext{
Cohort of 603 patients with BC; 112 fatal events; nutritional assessment by FFQ Block questionnaire. RR: 4.8 (1.3-18.1) and T: 0.08 in PRM women.

2 Cohort of 512 patients with BC. HR for mortality was $3.12(1.79-5.44)$ and $\mathrm{T}:<0.05$.
} 
intervention group was around $20 \%$, compared to $30 \%$ in the control group, at the end of the study. The lipid intake was $19 \mathrm{~g}$ and the weight $3 \mathrm{~kg}$ lower than the control group. The RR for relapse was $0.76(0.60-0.98$, T: 0.034) in women of the experimental group compared to the control group, and 0.58 (0.37-0.91, T: 0.018) for women with estrogen receptor tumors.

Another randomized controlled intervention study with 1,537 women in the experimental group and 1,552 in the control group focused not only on lipid intake reduction (15-20\% of TEI), but also on increased intake of fiber (30 g/day), fruit and vegetables. After a 6-year follow-up, the vegetable intake was increased from $3.9 \pm 0.05$ to 5.8 \pm 0.09 servings/day after 6 years, only in the experimental group, but fruit intake remained stable, as well as the lipid intake at around $28 \%$ of TEI without ever reaching the target. Moreover, both groups reported a lower energy intake after 6 years (experimental: 1,719 to 1,538 kcal/day; control: 1,717 to $1,559 \mathrm{kcal} /$ day), whereas weight increased in both groups (experimental: 73.5 to $74.1 \mathrm{~kg}$; control 73.3 to $73.7 \mathrm{~kg}$ ). This casts a doubt on the accuracy of the nutritional assessment through self-report. Thus, the absence of difference in TEI and weight might explain the absence of difference in the selected end points (recurrence or death), and reinforces the assumption of weight loss having a major effect on BC survival.

There is limited evidence for a specific role of fat in decreasing the risk of invasive event or death in $\mathrm{BC}$ survivors, unless the decrease in total fat intake results in weight loss.

\section{Saturated FA}

The AFSSA report [2003] considered the results from the 2 national EPIC cohorts investigating SFA and BC risk. The French report showed a non-significant increased risk [Thiébaut et al., 2001], whereas the English report [Bingham et al., 2003] that used a more precise nutrition assessment (8 days registration) showed a significant relationship. Thus, it was concluded that the effect of SFA was similar to that of total fat. More recently, results from 2 cohort studies [Thiébaut et al., 2007; Sieri et al., 2008] showed a significant association, which was observed neither in a Swedish cohort study [Löf et al., 2007] nor in 2 case-control studies [Garcia-Segovia et al., 2006; Wang et al., 2008].

An indirect argument comes from a Japanese study reporting that POM women with an intake of SFA $>15 \%$ of TEI present a 7\% higher mammary density than POM women consuming $<15 \%$ of SFA of TEI [Nagata et al., 2005].

Total Fat, Fatty Acids Intake and Cancers
So, while data are limited, the results of the 2 large cohort studies suggest a possible relationship between high saturated fat intake and a modest increase in BC risk.

\section{Monounsaturated Fat}

As stated in the 2003 AFSSA report, in most of the North American and north European countries MUFA intakes present the same relationship to $\mathrm{BC}$ as total fat and/or SFA. This was also true in 2 case-control studies (France [Gerber et al., 2005] and USA [Wang et al., 2008]) and 1 cohort study in the USA [Thiébaut et al., 2007]. In these countries, the major contributor to MUFA intake was meat.

However, in Mediterranean countries, where olive oil is the major contributor to MUFA intakes, they were associated with a reduction in $\mathrm{BC}$ risk. The analysis based on foods showed that olive oil is responsible for the risk reduction. Two recent case-control studies support the observation of the first studies [Garcia-Segovia et al., 2006; Bessaoud et al., 2008].

The beneficial effect might be conjointly or individually attributed to 3 variables: (1) the presence of oleuropein, a phenolic compound capable of modulation of phase I and II enzymes, in olive oil [Gerber, 1997b]; (2) an effect of substitution of animal fat by vegetal fat: Rasmussen et al. [1996] showed that a test meal with butter is followed by a higher peak of insulinemia than a test meal with olive oil; (3) the context of the Mediterranean diet pattern might either participate in or confound the effect.

Thus, the data collected about MUFA underlines the importance of taking into consideration the source of FA and the global dietary pattern when judging beneficial or deleterious effects of these FA on cancers [Gerber, 2001; Fung et al., 2006].

\section{n-6 FA: Linoleic Acid}

It was noted in the AFSSA report 2003 that most of the epidemiological studies did not show any association between n-6 FA and LA, as opposed to the animal observations [Cohen et al., 1986]. Recent reports based on questionnaires [Gerber et al., 2005; Thiébaut et al., 2009] or biomarkers confirmed this observation [Gerber et al., 2005; Shannon et al., 2007; Kuriki et al., 2007]. However, while using adipose tissue FA measures treated by principal component analysis on 329 patients presenting BC and benign breast disease, Bougnoux et al. [2006] showed that LA was part of the 2nd component, explaining $18 \%$ of the interindividual variability and associated with $\mathrm{BC}$ risk (OR: 1.28; CI: 1.11-1.49). Such results deserve further investigation, particularly within a prospective design.

Ann Nutr Metab 2009;55:140-161 


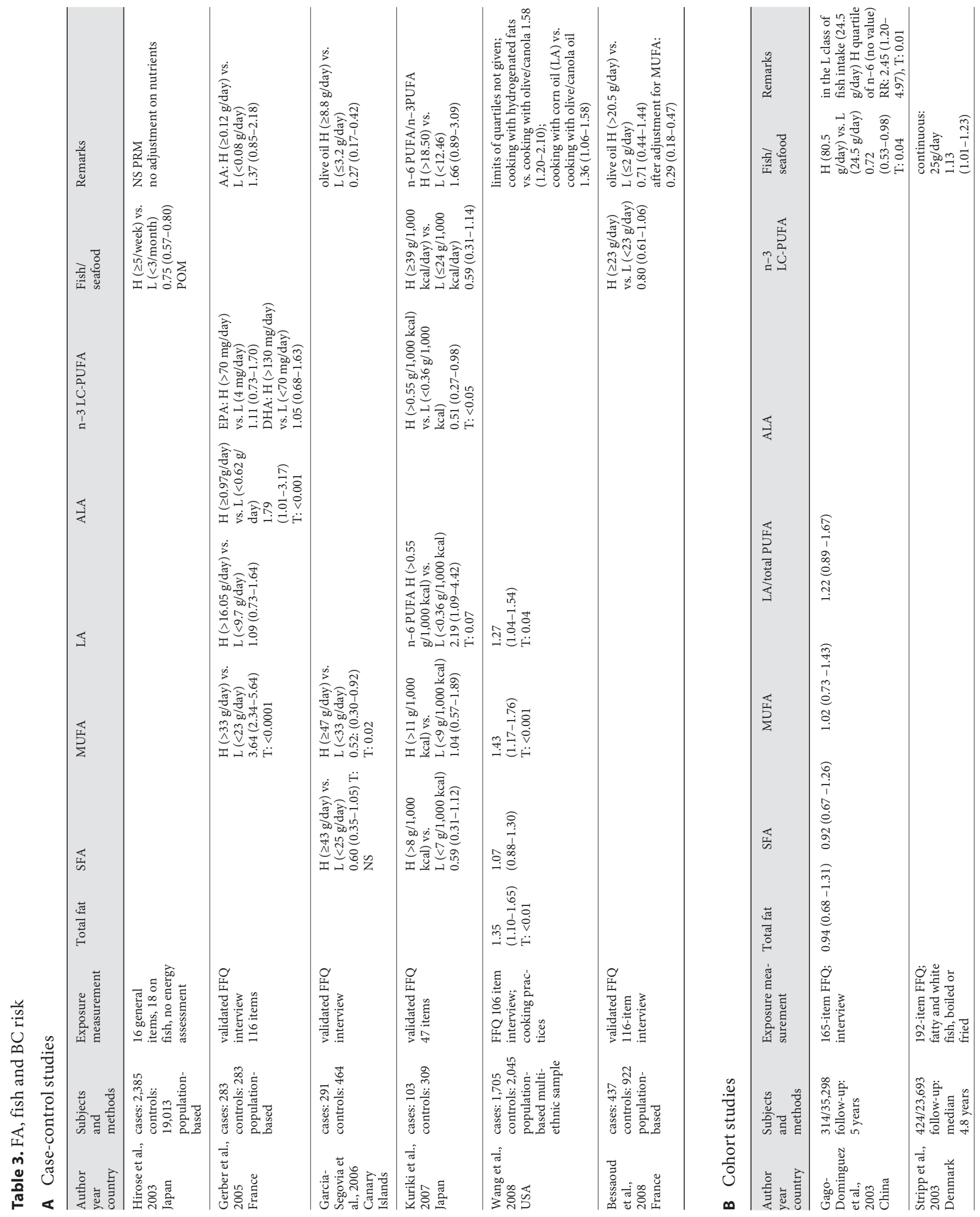




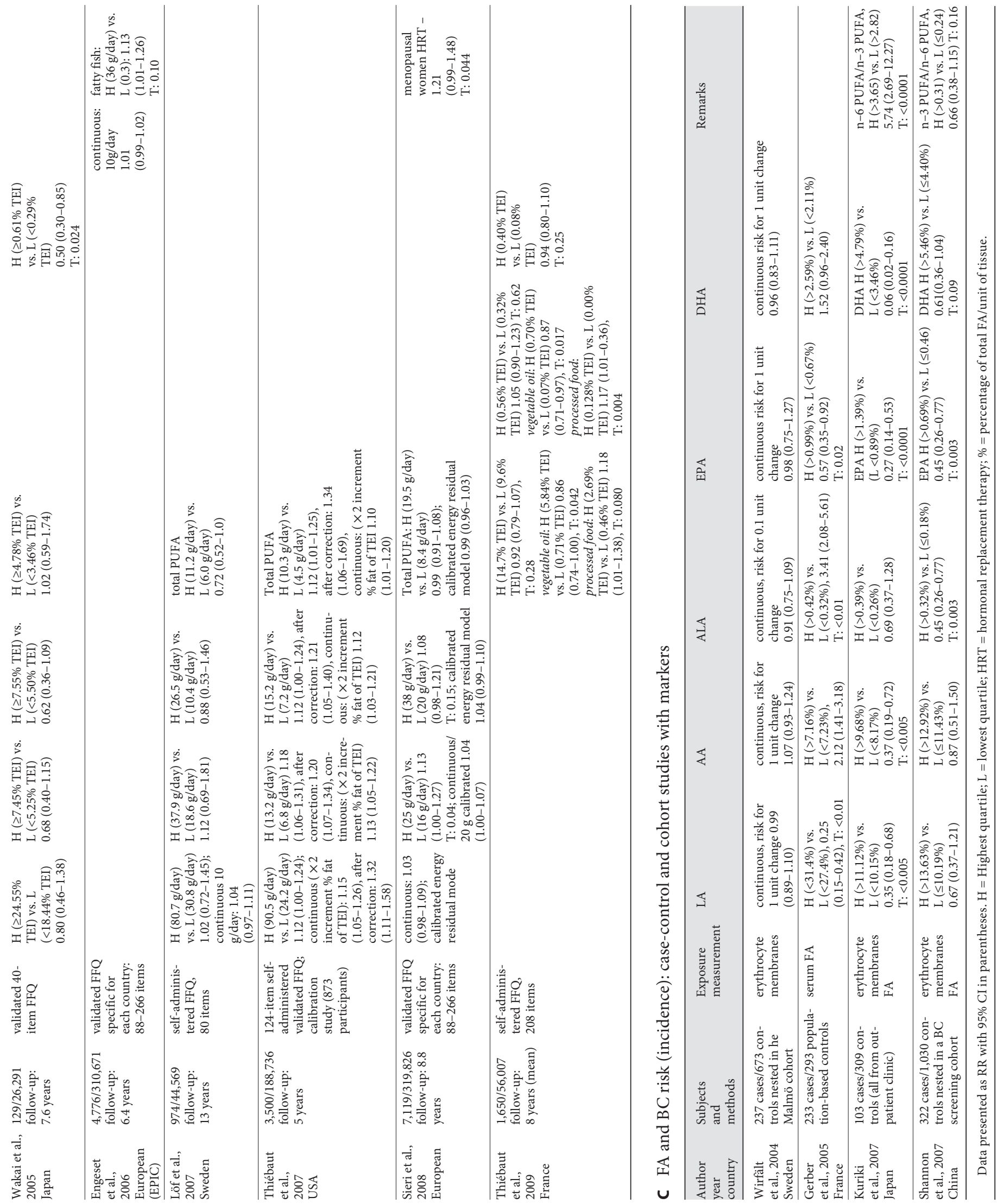


Another point, also discussed for CRC, is the importance of the food context. In the study reported by Thiébaut et al. [2009], LA from vegetable oils showed a decreased risk of borderline significance (HR: 0.86, CI: 0.74-1.00, T: 0.042), whereas LA from processed food was associated with an increased risk (HR: 1.18, CI: 1.01-1.38, T: 0.080) (table 3B).

Nevertheless, based on the current data, no firm conclusion regarding $\mathrm{LA}$ and $\mathrm{BC}$ can be drawn.

\section{n-3 FA: Linolenic Acid}

Results concerning this FA are few and contradictory, as noted in the AFSSA report [2003].

However, in the case of ALA, like LA, the food context appears to play a role. In the study by Thiébaut et al. [2009], ALA from vegetable oils showed a decreased risk (HR: 0.87, CI: 0.71-0.97, T: 0.017), whereas ALA from processed food and especially mixed nuts was associated with increased risk (HR: 1.17, CI: 1.01-0.36, T: 0.004) (table 3B).

Due to the lack of clear data, as with n-6, no satisfactory conclusion can currently be drawn.

\section{n-3 FA: Long-Chain Polyunsaturated FA}

In all populations, the major contributor of $n-3 \mathrm{LC}$ PUFA (EPA and DHA) is seafood. Therefore, the relationship to fish intake, which is the most generally estimated, is considered in this section.

In spite of the 17 case-control and 4 prospective studies covered in the AFSSA report [2003], no conclusion could be put forward because the data were contradictory. Since then, 2 prospective studies [Stripp et al., 2003; Engeset et al., 2006] and 3 case-control studies [Hirose et al., 2003; Kuriki et al., 2007; Bessaoud et al., 2008] investigating the relationship between fish/seafood intake and $\mathrm{BC}$ have been published. In the Asian and southern French studies, fish consumption is only significantly associated with BC risk reduction in the study of Hirose et al. [2003]. On the other hand, the 2 prospective studies conducted in northern Europe showed a risk increase associated with fatty fish consumption [Engeset et al., 2006] and total consumption in the Danish study [Stripp et al., 2003].

With regard to n-3 LC-PUFA, the AFSSA report [2003] concluded that there was an absence of effect for EPA and limited but suggestive evidence for a protective effect of DHA. Since this report, 3 prospective studies [GagoDominguez et al., 2003; Wakai et al., 2005; Thiébaut et al., 2009], 2 case-control studies [Gerber et al., 2005; Kuriki et al., 2007] with questionnaires, 2 case-control studies and 2 prospective studies investigating the relationship between $\mathrm{BC}$ risk and EPA/DHA either in sera or in erythrocyte membranes [Wirfält et al., 2004; Gerber et al., 2005; Kuriki et al., 2007; Shannon et al., 2007] have been published. They showed also a risk reduction in Asian countries and southern France (EPA) and no effect in Denmark, Sweden or the whole of France (table 3).

In countries with a beneficial food pattern, as in Asian and Mediterranean countries, the highest intake of fish or n-3 LC-PUFA is associated with a risk reduction in $\mathrm{BC}$, whereas there is either no effect or an association with an increased risk in northern European countries. Thus, there is limited but suggestive evidence that a highto-moderate consumption of fish and n-3 LC-PUFA as part of a beneficial food pattern is associated with a reduced $\mathrm{BC}$ risk. Increased risk observed in some European countries might be related to a less favorable contextual food pattern and/or to possible endocrine disruptor pollutants known to be present in the seas around these countries [Hoyer et al., 1998].

\section{Relationship of $n-6$ and n-3 FA to PUFA/}

Antioxidants

Several studies [Simonsen et al., 1998; Bagga et al., 2002; Hermann et al., 2002; Maillard et al., 2002; Goodstine et al., 2003; Gago-Dominguez et al., 2003] have shown that the effect of n-3 FA on BC risk depends upon the relative amount of n-6 FA, and vice versa. Many of these studies had limitations, and recent reports are not consistent (table 3C) [Shannon et al., 2007; Kuruki et al., 2007]. These observations may simply reflect the difficulty in addressing specific FA in epidemiology when they are generally correlated.

Interactions with antioxidants also have been described, which alluded to the apoptotic effect of PUFA opposed by antioxidants. These include case-control and survival studies reporting on vitamin E [Gerber et al., 1989; Saintot et al., 2002] and prospective studies reporting on vitamin $C$ and $\beta$-carotene and/or vitamin $\mathrm{E}$ [Verhoeven et al.,1997; Michels et al., 2001; Njondock et al., 2003].

Experimental studies have provided mechanistic arguments supporting the tumor inhibitory effect of PUFA, related to the peroxidation products, and to their relationship with antioxidants. The latter block the cytotoxic effect of peroxidized PUFA and enhance tumor growth [Bougnoux, 1999].

Limited evidence has suggested that a high intake of n-6 FA together with a low intake of n-3 LC-PUFA might increase $\mathrm{BC}$ risk, and that high levels of antioxidants might oppose the apoptotic effect of n-3 LC-PUFA. 
Table 4. FA, fish and endometrium cancer risk (incidence): case-control studies

\begin{tabular}{|c|c|c|c|c|c|c|c|c|}
\hline $\begin{array}{l}\text { Author } \\
\text { year } \\
\text { country }\end{array}$ & $\begin{array}{l}\text { Subjects and } \\
\text { methods }\end{array}$ & $\begin{array}{l}\text { Exposure } \\
\text { measurement }\end{array}$ & Total fat & SFA & MUFA & LA & ALA & Remarks \\
\hline $\begin{array}{l}\text { Lucenteforte } \\
\text { et al., } 2008 \\
\text { Italy }\end{array}$ & $\begin{array}{l}454 \text { cases/ } \\
908 \text { hospital- } \\
\text { based } \\
\text { controls }\end{array}$ & FFQ 78 items & $1.1(0.7-1.6)$ & $1.3(0.9-2.0)$ & $0.8(0.6-1.2)$ & $\begin{array}{l}0.9 \\
(0.6-1.4)\end{array}$ & $\begin{array}{l}1.0 \\
(0.7-1.6)\end{array}$ & $\begin{array}{l}\text { PUFA H ( }>6.1 \mathrm{~g} / 1,000 \mathrm{kcal} / \mathrm{day}) \\
\text { vs. } \mathrm{L}(<3.4 \mathrm{~g} / 1,000 \mathrm{kcal} / \mathrm{day}) \\
0.8(0.6-1.0) \\
\text { Cholesterol: } 2.1(1.4-3.2) \\
\text { limits of the quartiles not given }\end{array}$ \\
\hline
\end{tabular}

Data presented as OR with $95 \% \mathrm{CI}$ in parentheses. $\mathrm{H}=$ Highest quartile; $\mathrm{L}=$ lowest quartile.

Trans Fatty Acids

The WCRF/AICR [2007] panel concluded that any effects of trans FA specifically on any form of cancer are not known. The contradictory results presented in the 2003 AFSSA report did not allow any conclusion to be made. Since then, 1 case-control and 1 prospective study have shown an increased BC risk for women cooking with hydrogenated fats [Wang et al., 2008] and for women with a high percentage of trans FA in their serum phospholipids [Chajès et al., 2008].

Because animal models showed tumor inhibition after treatment by conjugated LA, the AFSSA report [2003] reviewed the human studies investigating this topic. The results were contradictory, so no conclusion could be put forward, and recent studies have offered no strong evidence to warrant a revision of this decision.

\section{Endometrial Cancer}

Endometrial cancer (EC) is the eighth most common cancer in women worldwide, and is more frequent in high-income countries. The prognosis is generally favorable, and about $75 \%$ of patients survive for 5 years. EC occurs mainly after menopause, and is strongly associated to obesity. It might be considered as hormone dependent, and changes in hormone levels associated with metabolic syndrome are likely to play a part in the development of EC [Cust et al., 2007].
The WCRF/AICR [2007] panel concluded that body fatness (convincingly) and abdominal fatness (probably) increase the risk of developing EC. Recently, 2 cohort studies and 9 case-control studies were included in a meta-analyses, but the sole cohort study evaluating total fat and saturated fat did not find an association [Bandera et al., 2007]. Thus, the random-effects summary estimates were based only on case-control studies and were $1.24(1.10-1.41)$ per $10 \% \mathrm{kcal}$ from total fat and $1.28(1.12$ 1.47) per $10 \mathrm{~g} / 1,000 \mathrm{kcal}$ of saturated fat. For animal fat (per $10 \mathrm{~g} / 1,000 \mathrm{kcal}$ ) the summary estimates were 0.78 (0.63-0.96) and 1.34 (1.06-1.69) for 2 cohort and 4 casecontrol studies, respectively.

Since this meta-analysis, 3 other case-control studies have been published (table 4). Dalvi et al. [2007] looked at dietary patterns but mainly individualized a risk associated with fat intake, whatever the amount of fruit and vegetables consumed. Xu et al. [2007] in Shanghai underlined the animal origin of fat as a risk factor for EC. In a study conducted in Italy, Lucenteforte et al. [2008] reported several arguments suggesting that animal fat confers a higher risk than vegetable fat. Finally in the low-fat WHI intervention trial, there was a weak reduction in EC in the experimental group ( $\mathrm{HR}=0.95, \mathrm{CI}: 0.89-1.01$, T: 0.10) [Prentice et al., 2007].

As for BC, total fat very likely contributes to increasing EC risk through constitution of body fatness, and animal fat in particular appears to be responsible for this risk increase.

Ann Nutr Metab 2009;55:140-161 155 


\section{Ovarian Cancer}

Ovarian cancer (OC) is the seventh most common cancer in women worldwide, and also the seventh most common cause of cancer death. It is more frequent in high-income countries. OC shares several risk factors with $\mathrm{BC}$ as a hormone-dependent cancer. Among these common factors, only 1 , adult attained height, appears to be related to nutrition, and is recognized as such in the WCRF/AICR report [2007]. Since then, 631 incident cases of invasive epithelial OC and 1,174 matched controls were analyzed in Israel [Lubin et al., 2006]. Substituting non-animal fat in preference to animal fat over a relatively short-term period (between 2 and 7 years prior to interview) decreased the risk of OC (OR: 0.65 per 100 kcal, CI: $0.50-0.85)$. Also, a pooled analysis of 12 cohorts (523,217 women and 2,132 OC cases) showed borderline significant increases in $\mathrm{OC}$ for the highest versus the lowest quartile of SFA intake (1.14, CI: 0.97-1.34, T: 0.22) and in animal fat (1.15, CI: 0.99-1.33, T: 0.15) [Genkinger et al., 2006]. More recently, the results of the WHI lowfat trial relative to OC showed that after a follow-up of 4 years, there was a significantly lower OC risk $(0.60, \mathrm{CI}$ : 0.38-0.96) [Prentice et al., 2007]. However, it could be that the effect is mediated by weight loss.

With these more recent reports, there is limited evidence suggestive of a deleterious effect of fat, especially animal fat, on OC.

\section{Conclusion}

The relationship between fat and cancer has been extensively investigated for more than 2 decades, and is still being debated in spite of numerous studies and improvements in food composition tables, epidemiological and statistical methods. If the highly multifactorial character of cancers is part of the complexity, 2 questions are crucial to understand why a firm conclusion is difficult to establish:

- Since there is convincing evidence that obesity increases the risks for CRC, EC and POM BC, does fat contribute to obesity? Although the answer to this question can be found in the background review paper on fat intake and overweight, obesity, metabolic syndrome (Melanson et al., this issue), the strength of the evidence supporting an association of total fat with cancers will be summarized below.

- Do FA play a specific part in cancer development beyond their contribution to energy? This question might also be difficult to answer for FA that represent a high percentage of total lipid intake (SFA, MUFA) and are confounded by energy. The percentage of PUFA, especially $n-3$, and trans FA in total lipid intake is much lower and a possible specific activity could be more easily determined. However, foods that contribute mainly to their intake carry special characteristics. For example, the source of n-3 LC-PUFA is essentially fish, and fish is also a source of vitamin $\mathrm{D}$ and of selenium, both being credited with a possible protective effect against some cancers. Thus, if a risk reduction associated with fish is observed, it might be due totally or in part to these other nutrients. Also, if fish is substituted for meat (a recognized risk factor for CRC), fish and its nutrients might be incorrectly considered responsible of the observed risk reduction, when the effect is related to a different food pattern. For trans FA, they are generally found in processed foods, part of Western diet pattern that is often described as a risk factor for several cancers.

Thus, epidemiology by itself may lack the power to bring sufficient evidence for firm conclusions concerning whether or not the quantity or type of fat in the diet has any effect on the risk of developing any type of cancer. Experimental studies and biological plausibility may bring complementary lines of evidence and might help to reach a conclusion in some situations. We can raise the question: is it currently possible to give figures of FA intake aimed to prevent cancer risk after a literature review of the association of FA intake and risk of cancer incidence?

Since it has been proposed to use disease outcome as an indicator of adequacy or optimal intake, then as a criterion for dietary FA recommendations, the summary will examine the relationship of total fat and FA and cancers in the perspective of quantification.

This exercise is constrained by several limitations: many of the studies do not precisely define the FA amount associated with cancer risk; the FFQ, which is the main tool for exposure assessment, is subjected to measurement error [Bingham et al., 2003]; hence, the exposure values are supposed to classify the cases relatively to controls, and cannot be considered as absolute. However, if several different studies come out with comparable figures, one could tentatively work out a range of values for recommendations.

\section{Total Fat}

Several studies have shown that total fat is associated with CRC, BC, EC and OC. Experimental studies in animal models support a direct relationship. Inasmuch as fat is related to obesity, there is biological plausibility. 
With regard to CRC, effects of total fat appear to be confounded by the energy conveyed by total fat.

For EC, a meta-analysis of 9 case-control studies, and 3 recent studies agree on an association of total fat with an increased risk, but 2 prospective studies did not. One can conclude that limited data are suggestive of a probable relationship between total fat and EC. Since obesity is the main risk factor for EC, it is likely that total fat plays a role through obesity constitution.

For OC, there are few studies, but there is an intervention assay with clear significant results; thus, one can conclude there are limited data suggestive of a direction towards a relationship between total fat and OC.

For BC, not all the studies are in agreement. However, at least 5 case-control studies, a recent cohort and an intervention assay have provided data suggestive of a probable relationship between total fat and $\mathrm{BC}$, which might act through obesity. Heterogeneity could be explained by different food patterns where energy is provided by other nutrients (e.g. carbohydrates in Asian countries).

Data for BC cancer survivors are scarce, but go in the same direction as observations made prior to cancer diagnosis.

For BC, EC and OC, a quantification approach can be proposed with the data at hand: a total fat intake between 30 and $33 \%$ of TEI is not associated with increased risk of these 3 cancers.

\section{SFA, MUFA and Animal Fat}

The effects of these FA on CRC are comparable to total fat for CRC. It appears from the limited data at hand that SFA could increase BC risk, but only moderately, and not an SFA intake $\leq 11 \%$.

Animal fat has been especially mentioned for EC and $\mathrm{OC}$, but the data are too few to come to a conclusion. Also, SFA has been reported to increase the risk of progression to PC, but again the data are insufficient to form any conclusions.

\section{n-6 FA (LA) and n-3 FA (ALA)}

Contrarily to animal studies, most epidemiological studies do not show any association of LA and n-6 FA with CRC, PC and BC. This may be explained by a difference in the proportion of FA in the diet, or by the part played by the diversification of foods in the human food pattern.

Contradictory results have been reported for ALA. Thus, there are no data with which to form a recommendation related for these FA.

\section{n-3 LC-PUFA}

There are several epidemiological studies showing a probable risk reduction for CRC by fish intake, but the data are more limited for the n-3 LC-PUFA provided by fish intake. Residual confounding with other fish nutrients cannot be excluded, given that EPA and DHA are strongly correlated with fish intake. In the same line, meat substitution by fish may confound the effect.

Therefore, we have to ask the question: is it possible to make a recommendation concerning n-3 LC-PUFA? There are several arguments to support a proper role of n-3 LC-PUFA: they have been shown in tumor animal models to oppose tumor growth through apoptosis induction, and the anti-inflammatory effect of EPA has been recognized. Human studies on gene polymorphisms of the COX2 enzyme and the observation of different effects in subjects receiving/not receiving aspirin support the plausibility of the effect in humans.

Data are limited, but suggestive of a risk reduction in BC with higher intake of $n-3$ LC-PUFA. They are even more limited for PC, but suggestive of a direction toward a risk reduction.

All studies at hand with quantification agree that an intake $\geq 500 \mathrm{mg}$ EPA + DHA daily is necessary for a significant risk reduction of $20-25 \%$. In Asian countries, $\geq 1,500 \mathrm{mg} /$ day significantly decreased BC risk by $50 \%$, but the a question remains of how important it is that fish provide these FA.

\section{n-6 PUFA/n-3 PUFA}

Several studies have reported that a high ratio of n-6:n-3 FA is associated with an increased risk of CRC, PC and BC. Since a risk associated with $n-6$ has not been demonstrated, a low n-3 PUFA intake would be responsible for the observation. If the intake of EPA and DHA is increased as recommended above, the ratio is likely to improve.

\section{trans Fatty Acids}

There is not a large body of evidence to support either the deleterious or the beneficial effect of trans FA and conjugated LA with regard to cancers (3 studies in PC and 2 in BC showed a deleterious effect). The studies in PC are interesting in that they suggest a mechanistic hypothesis based on an opposite effect of trans FA to n-3 LCPUFA. On the one hand, there is interference from the RNAse L polymorphism (enzyme involved in a pro-apoptosis); on the other hand, a different effect in subjects taking or not taking aspirin. However, there is not enough data to make a recommendation with regard to cancers.

Ann Nutr Metab 2009;55:140-161 
Finally, several studies have pointed out the importance of the quality of food (animal vs. vegetal, processed vs. non-processed) contributing to the FA intake pattern. Recommendations may have to take into consideration the food context of the FA to weigh their roles in disease outcome.

\section{Disclosure Statement}

Dr. Gerber conducted research supported by the French Federation of Fat Industrial Companies and has participated in committees of the French Food Safety Agency on fatty acids and cancers, trans fatty acids and population reference intakes for lipids.

\section{References}

AFSSA: AFSSA report 2003: Acides gras alimentaires et cancers: état des connaissances et perspectives. Paris, AFSSA, 2003.

-Astorg P, Arnault N, Czernichow S, Noisette N, Galan P, Hercberg S: Dietary intakes and food sources of n-6 and n-3 PUFA in French adult men and women. Lipids 2004;39:527535.

-Bagga D, Anders KH, Wang HJ, Glaspy JA: Longchain n-3-to-n-6 polyunsaturated fatty acid ratios in breast adipose tissue from women with and without breast cancer. Nutr Cancer 2002;42:180-185.

- Bandera EV, Kushi LH, Moore DF, Gifkins DM, McCullough ML: Dietary lipids and endometrial cancer: the current epidemiologic evidence. Cancer Causes Control 2007;18: 687-703.

-Berrino F, Bellati C, Secreto G, Camerini E, Pala V, Panico S, Allegro G, Kaaks R: Reducing bioavailable sex hormones through a comprehensive change in diet: the diet and androgens (DIANA) randomized trial. Cancer Epidemiol Biomarkers Prev 2001;10:25-33.

Bessaoud F, Daurès JP, Gerber M: Dietary factors and breast cancer risk: a case control study among a population in Southern France. Nutr Cancer 2008;60:177-187.

-Bidoli E, Talamini R, Bosetti C, Negri E, Maruzzi D, Montella $\mathrm{M}$, Franceschi S, La Vecchia C: Macronutrients, fatty acids, cholesterol and prostate cancer risk. Ann Oncol 2005; 16:152-157.

Bingham SA, Luben R, Welch A, Wareham N, Khaw KT, Day N: Are imprecise methods obscuring a relation between fat and breast cancer? Lancet 2003;362:212-214.

Borugian MJ, Sheps SB, Kim-Sing C, Van Patten C, Potter JD, Dunn B, Gallagher RP, Hislop TG: Insulin, macronutrient intake, and physical activity: are potential indicators of insulin resistance associated with mortality from breast cancer? Cancer Epidemiol Biomarkers Prev 2004;13:1163-1172.

Bougnoux P: n-3 polyunsaturated fatty acids and cancer. Curr Opin Clin Nutre Metab Care 1999;2:121-126.

Bougnoux P, Giraudeau B, Couet C: Diet, cancer and the lipidome. Cancer Epidemiol Biomarkers Prev 2006;15:416-421.

-Chajès V, Thiébaut ACM, Rotival M, Gauthier E, Maillard V, Boutron-Ruault MC, Joulin V, Lenoir GM, Clavel-Chapelon F: Association between serum trans-monounsaturated fatty acids and breast cancer risk in the $\mathrm{E} 3 \mathrm{~N}$ EPIC study. Amer J Epidemiol 2008;167: 1312-1320.

- Chang WL, Chapkin RS, Lupton JR: Fish oil blocks azoxymethane-induced rat colon tumorigenesis by increasing cell differentiation and apoptosis rather than decreasing cell proliferation. J Nut 1998;128:491-497.

Chavarro JE, Stampfer MJ, Li H, Campos H, Kurth T, Ma J: A prospective study of polyunsaturated fatty acid levels in blood and prostate cancer risk. Cancer Epidemiol Biomarkers Prev 2007;16:1364-1370.

Chavarro JE, Stampfer MJ, Campos H, Kurth T, Willett WC, Ma J: A prospective study of trans-fatty acid levels in blood and risk of prostate cancer. Cancer Epidemiol Biomarkers Prev 2008;17:95-101.

-Chlebowski RT, Blackburn GL, Thomson CA, Nixon DW, Shapiro A, Hoy MK, Goodman MT, Giuliano AE, Karanja N, McAndrew P, Hudis C, Butler J, Merkel D, Kristal A, Caan B, Michaelson R, Vinciguerra V, Del Prete S, Winkler M, Hall R, Simon M, Winters BL, Elashoff RM: Dietary fat reduction and breast cancer outcome: interim efficacy results from the Women's Intervention Nutrition Study. J Natl Cancer Inst 2006;98:1767-1776.

CNERNA, CNRS: Alimentation et cancer: évaluation des données scientifiques. Riboli E, Decloître F, Collet-Ribbing C (eds): Tec \& Doc; 1996.

Cohen LA, Thompson DO, Maeura Y, Choi K, Blank ME, Rose DP: Dietary fat and mammary cancer. I. Promoting effects of different dietary fats on $\mathrm{N}$-nitrosomethylurea-induced rat mammary tumorigenesis. J Nat Cancer Inst 1986;77:33-42.

COMA: Nutritional aspects of development of cancer: report of the working group on Diet and Cancer of the Committee on Medical Aspects of Food and Nutrition Policy. London: The Stationery Office, 1998.

Cust AE, Kaaks R, Friedenreich C, Bonnet F, Laville M, Tjønneland A, Olsen A, Overvad K, Jakobsen MU, Chajès V, Clavel-Chapelon F, Boutron-Ruault MC, Linseisen J, Lukanova A, Boeing H, Pischon T, Trichopoulou A, Christina B, Trichopoulos D, Palli D, Berrino F, Panico S, Tumino R, Sacerdote C, Gram IT, Lund E, Quirós JR, Travier N, MartínezGarcía C, Larrañaga N, Chirlaque MD, Ar- danaz E, Berglund G, Lundin E, Bueno-deMesquita HB, van Duijnhoven FJ, Peeters PH, Bingham S, Khaw KT, Allen N, Key T, Ferrari P, Rinaldi S, Slimani N, Riboli E: Metabolic syndrome, plasma lipid, lipoprotein and glucose levels, and endometrial cancer risk in the European Prospective Investigation into Cancer and Nutrition (EPIC).

Endocr Relat Cancer 2007;14:755-767.

Dalvi TB, Canchola AJ, Horn-Ross PL: Dietary patterns, Mediterranean diet, and endometrial cancer risk. Cancer Causes Control 2007;18:957-966.

-Engeset D, Alsaker E, Lund E, Welch A, Khaw KT, Clavel-Chapelon F, Thiébaut A, Chajès V, Key TJ, Allen NE, Amiano P, Dorronsoro M, Tjønneland A, Stripp C, Peeters PH, van Gils CH, Chirlaque MD, Nagel G, Linseisen J, Ocké MC, Bueno-de-Mesquita HB, Sacerdote C, Tumino R, Ardanaz E, Sánchez MJ, Panico S, Palli D, Trichopoulou A, Kalapothaki V, Benetou V, Quirós JR, Agudo A, Overvad K, Bjerregaard L, Wirfält E, Schulz M, Boeing H, Slimani N, Riboli E: Fish consumption and breast cancer risk: The European Prospective Investigation into Cancer and Nutrition (EPIC). Int J Cancer 2006;119: 175-182.

- Engeset D, Andersen V, Hjartaker A, Lund E: Consumption of fish and risk of colon cancer in the Norwegian Women and Cancer (NOWAC) study. Br J Nutr 2007;98:576582.

English DR, MacInnis RJ, Hodge AM, Hopper JL, Haydon AM, Giles GG: Red meat, chicken, and fish consumption and risk of colorectal cancer. Cancer Epidemiol Biomarkers Prev 2004;13:1509-1514.

FAO: Fats and Oils in Human Nutrition: Report of a Joint FAO/WHO Expert Consultation. Rome, FAO, 1994

Flood A, Rastogi T, Wirfält E, Mitrou PN, Reedy J, Subar AF, Kipnis V, Mouw T, Hollenbeck AR, Leitzmann M, Schatzkin A: Dietary patterns as identified by factor analysis and colorectal cancer among middle-aged Americans. Am J Clin Nutr 2008;88:176-184.

Fung TT, Hu FB, Holmes MD, Rosner BA, Hunter DJ, Colditz GA, Willett WC: Dietary patterns and the risk of postmenopausal breast cancer. Int J Cancer 2005;116:116-121.

-Gago-Dominguez M, Yuan JM, Sun CL, Lee HP, Yu MC: Opposing effects of dietary $n-3$ and 
n-6 fatty acids on mammary carcinogenesis: The Singapore Chinese Health Study. Br J Cancer 2003;89:1686-1692.

-Galeone C, Talamini R, Levi F, Pelucchi C, Negri E, Giacosa A, Montella M, Franceschi S, La Vecchia C: Fried foods, olive oil and colorectal cancer. Ann Oncol 2007;18:36-39.

-Garcia-Segovia P, Sanchez-Villegas A, Doreste J, Santana F, Serra-Majem L: Olive oil consumption and risk of breast cancer in the Canary Islands: a population-based casecontrol study. Public Health Nutr 2006;9: 163-167.

Geelen A, Schouten JM, Kamphuis C, Stam BE, Burema J, Renkema JM, Bakker EJ, Van't Veer P, Kampman E: Fish consumption, n-3 fatty acids, and colorectal cancer: a metaanalysis of prospective cohort studies. Am J Epidemiol 2007;166:1116-1125.

-Genkinger JM, Hunter DJ, Spiegelman D, Anderson KE, Beeson WL, Buring JE, Colditz GA, Fraser GE, Freudenheim JO, Goldbohm RA, Hankinson SE, Koenig KL, Larsson SC, Leitzmann M, McCullough M, Miller AB, Rodriguez C, Rohan TE, Ross JA, Schatzkin A, Schouten LJ, Smit E, Willett WC, Wolk A, Zeleniuch-Jacquotte A, Zhang SM, SmithWarner SA: A pooled analysis of 12 cohort studies of dietary fat, cholesterol and egg intake and ovarian cancer. Cancer Causes Control 2006;17:273-285.

- Gerber M, Richardson S, Crastes de Paulet P, Pujol H, Crastes de Paulet A: Relationship between vitamin $\mathrm{E}$ and polyunsaturated fatty acids in breast cancer: nutritional and metabolic aspects. Cancer 1989;64:2347-2353.

- Gerber M: Reversal of relation between body mass and endogenous estrogen concentrations with menopausal status. J Natl Cancer Inst 1997a;89:661-662.

-Gerber M: Olive oil, monounsaturated fatty acids and cancer. Cancer Lett 1997b;114:9192.

-Gerber M, Scali J, Michaud A, Durand M, Astre C, Dallongeville J, Romon M: Profiles of a healthy diet and its relationship with biomarkers in a population sample from Mediterranean southern France. J Amer Diet Assoc 2000;100:1164-1171.

Gerber M: The comprehensive approach to diet: a critical review. J Nutr 2001;131:3051S3055S

-Gerber M, Thiébaut A, Astorg P, Clavel-Chapelon F, Combe N: Dietary fat, fatty acid composition and risk of cancer. Eur J Lipid Sci Technol 2005;107:540-559.

Giovannucci E, Liu Y, Platz EA, Stampfer MJ, Willett WC: Risk factors for prostate cancer incidence and progression in the health professionals follow-up study. Int J Cancer 2007; 121:1571-1578.

Goodstine SL, Zheng T, Holford TR, Ward BA, Carter D, Owens PH, Mayne ST: Dietary $(n-3) /(n-6)$ fatty acid ratio: possible relationship to premenopausal but not postmenopausal breast cancer risk in US women. J Nutr 2003;133:1409-1414.
Hall MN, Campos H, Li H, Sesso HD, Stampfer MJ, Willett WC, Ma J: Blood levels of longchain polyunsaturated fatty acids, aspirin, and the risk of colorectal cancer. Cancer Epidemiol Biomarkers Prev 2007;16:314-321.

Hall MN, Chavarro JE, Lee IM, Willett WC, Ma J: A 22-year prospective study of fish, n-3 fatty acid intake, and colorectal cancer risk in men. Cancer Epidemiol Biomarkers Prev 2008; 17:1136-1143.

Hedelin M, Chang ET, Wiklund F, Bellocco R, Klint A, Adolfsson J, Shahedi K, Xu J, Adami HO, Gronberg H, Balter KA: Association of frequent consumption of fatty fish with prostate cancer risk is modified by COX-2 polymorphism. Int J Cancer 2007;120:398-405.

-Hermann S, Linseisen J, Chang-Claude J: Nutrition and breast cancer risk by age 50 : a population-based case-control study in Germany. Nutr Cancer 2002;44:23-34.

Hill AB: The environment and disease: association or causation? Proc R Soc Med 1965;58: 295-300

Hirose K, Takezaki T, Hamajima N, Miura S, Tajima K: Dietary factors protective against breast cancer in Japanese premenopausal and postmenopausal women. Int J Cancer 2003; 107:276-282.

Hoyer AP, Grandjean P, Jørgensen T, Brock JW, Hartvig HB: Organochlorine exposure and risk of breast cancer. Lancet 1998;352:18161820 .

Hu J, Mery L, Desmeules M, Macleod M: Diet and vitamin or mineral supplementation and risk of rectal cancer in Canada. Acta Oncol 2007;46:342-354.

Kaaks R, Bellati C, Venturelli E, Rinaldi S, Secreto G, Biessy C, Pala V, Sieri S, Berrino F. Effects of dietary intervention on IGF-I and IGF-binding proteins, and related alterations in sex steroid metabolism: the Diet and Androgens (DIANA) Randomised Trial. Eur J Clin Nutr 2003;57:1079-1088.

Karmali RA, Reichel P, Cohen LA, Terano T, Hirai A, Tamura Y, Yoshida S: The effects of dietary n-3 fatty acids on the DU-145 transplantable human prostatic tumor. Anticancer Res 1987;7:1173-1179.

- Kimura Y, Kono S, Toyomura K, Nagano J, Mizoue T, Moore MA, Mibu R, Tanaka M, Kakeji Y, Maehara Y, Okamura T, Ikejiri K, Futami K, Yasunami Y, Maekawa T, Takenaka K, Ichimiya H, Imaizumi N: Meat, fish and fat intake in relation to subsite-specific risk of colorectal cancer: The Fukuoka Colorectal Cancer Study. Cancer Sci 2007;98:590-597.

King IB, Kristal AR, Schaffer S, Thornquist M, Goodman GE: Serum trans-fatty acids are associated with risk of prostate cancer in beta-Carotene and Retinol Efficacy Trial. Cancer Epidemiol Biomarkers Prev 2005; 14 : 988-992.

Kojima M, Wakai K, Tokudome S, Suzuki K, Tamakoshi K, Watanabe Y, Kawado M, Hashimoto S, Hayakawa N, Ozasa K, Toyoshima H, Suzuki S, Ito Y, Tamakoshi A: Serum levels of polyunsaturated fatty acids and risk of colorectal cancer: a prospective study. Am J Epidemiol 2005;161:462-471.

Kurahashi N, Inoue M, Iwasaki M, Sasazuki S, Tsugane AS, Japan Public Health CenterBased Prospective Study Group: Dairy product, saturated fatty acid, and calcium intake and prostate cancer in a prospective cohort of Japanese men. Cancer Epidemiol Biomarkers Prev 2008;17:930-937.

Kuriki K, Hirose K, Wakai K, Matsuo K, Ito H, Suzuki T, Hiraki A, Saito T, Iwata H, Tatematsu M, Tajima K: Breast cancer risk and erythrocyte compositions of $n-3$ highly unsaturated fatty acids in Japanese. Int J Cancer 2007; 121:377-385.

Lajous M, Boutron-Ruault MC, Fabre A, ClavelChapelon F, Romieu I: Carbohydrate intake, glycemic index, glycemic load, and risk of postmenopausal breast cancer in a prospective study of French women. Am J Clin Nutr 2008;87:1384-1391.

-Larsson SC, Rafter J, Holmberg L, Bergkvist L, Wolk A: Red meat consumption and risk of cancers of the proximal colon, distal colon and rectum: the Swedish Mammography Cohort. Int J Cancer 2005;113:829-834.

- Liu X, Schumacher FR, Plummer SJ, Jorgenson E, Casey G, Witte JS: Trans fatty acid intake and increased risk of advanced prostate cancer: modification by RNASEL R462Q variant. Carcinogenesis 2007;28:1232-1236.

-Löf M, Sandin S, Lagiou P, Hilakivi-Clarke L, Trichopoulos D, Adami HO, Weiderpass E: Dietary fat and breast cancer risk in the Swedish women's lifestyle and health cohort. Br J Cancer 2007;97:1570-1576.

Lubin F, Chetrit A, Modan B, Freedman LS: Dietary intake changes and their association with ovarian cancer risk. J Nutr 2006;136: 2362-2367.

Lucenteforte E, Talamini R, Montella M, Dal Maso L, Tavani A, Deandrea S, Pelucchi C, Greggi S, Zucchetto A, Barbone F, Parpinel M, Franceschi S, La Vecchia C, Negri E: Macronutrients, fatty acids and cholesterol intake and endometrial cancer. Ann Oncol 2008;19:168-172.

Lüchtenborg M, Weijenberg MP, de Goeij AF, Wark PA, Brink M, Roemen GM, Lentjes MH, de Bruine AP, Goldbohm RA, van't Veer P, van den Brandt PA: Meat and fish consumption, APC gene mutations and hMLH1 expression in colon and rectal cancer: a prospective cohort study (The Netherlands). Cancer Causes Control 2005;16:1041-1054.

- Maillard V, Bougnoux P, Ferrari P, Jourdan ML, Pinault M, Lavillonnière F, Body G, Le Floch $\mathrm{O}$, Chajès $\mathrm{V}: \mathrm{n}-3$ and $\mathrm{n}-6$ fatty acids in breast adipose tissue and relative risk of breast cancer in a case-control study in Tours, France. Int J Cancer 2002;98:78-83.

McEligot AJ, Largent J, Ziogas A, Peel D, AntonCulver H: Dietary fat, fiber, vegetable, and micronutrients are associated with overall survival in postmenopausal women diagnosed with breast cancer. Nutr Cancer 2006; 55:132-140. 
-Michels KB, Holmberg L, Bergkvist L, Ljung H, Bruce A, Wolk A: Dietary antioxidant vitamins, retinol, and breast cancer incidence in a cohort of Swedish women. Int J Cancer 2001;91:563-567.

- Nagata C, Matsubara T, Fujita H, Nagao Y, Shibuya C, Kashiki Y, Shimizu H: Associations of mammographic density with dietary factors in Japanese women. Cancer Epidemiol Biomarkers Prev 2005; 14:2877-2880.

Neuhouser ML, Barnett MJ, Kristal AR, Ambrosone CB, King I, Thornquist M, Goodman G: (n-6) PUFA increase and dairy foods decrease prostate cancer risk in heavy smokers. J Nutr 2007;137:1821-1827.

Njondock A, Shatenstein B, Ghadirian P: A casecontrol study of breast cancer and dietary intake of individual fatty acids and antioxidants in Montreal, Canada. Breast 2003;12: 128-135.

Norat T, Bingham S, Ferrari P, Slimani N, Jenab M, Mazuir M, Overvad K, Olsen A, Tjonneland A, Clavel F, Boutron-Ruault MC, Kesse E, Boeing H, Bergmann MM, Nieters A, Linseisen J, Trichopoulou A, Trichopoulos D, Tountas Y, Berrino F, Palli D, Panico $S$, Tumino R, Vineis P, Bueno-de-Mesquita HB, Peeters PH, Engeset D, Lund E, Skeie G, Ardanaz E, Gonzalez C, Navarro C, Quiros JR, Sanchez MJ, Berglund G, Mattisson I, Hallmans G, Palmqvist R, Day NE, Khaw KT, Key TJ, San Joaquin M, Hemon B, Saracci R, Kaaks R, Riboli E: Meat, fish, and colorectal cancer risk: the European Prospective Investigation into cancer and nutrition. J Natl Cancer Inst 2005;97:906-916.

-Oba S, Shimizu N, Nagata C, Shimizu H, Kametani M, Takeyama N, Ohnuma T, Matsushita S: The relationship between the consumption of meat, fat, and coffee and the risk of colon cancer: a prospective study in Japan. Cancer Lett 2006;244:260-267.

- Park SY, Murphy SP, Wilkens LR, Henderson BE, Kolonel LN: Fat and meat intake and prostate cancer risk: the multiethnic cohort study. Int J Cancer 2007;121:1339-1345.

- Pierce JP, Natarajan L, Caan BJ, Parker BA, Greenberg ER, Flatt SW, Rock CL, Kealey S, Al-Delaimy WK, Bardwell WA, Carlson RW, Emond JA, Faerber S, Gold EB, Hajek RA, Hollenbach K, Jones LA, Karanja N, Madlensky L, Marshall J, Newman VA, Ritenbaugh C, Thomson CA, Wasserman L, Stefanick ML: Influence of a diet very high in vegetables, fruit, and fiber and low in fat on prognosis following treatment for breast cancer: the Women's Healthy Eating and Living (WHEL) randomized trial. JAMA 2007;298 289-298.

Prentice RL, Caan B, Chlebowski RT, Patterson R, Kuller LH, Ockene JK, Margolis KL, Limacher MC, Manson JE, Parker LM, Paskett E, Phillips L, Robbins J, Rossouw JE, Sarto GE, Shikany JM, Stefanick ML, Thomson CA, Van Horn L, Vitolins MZ, Wactawski-Wende J, Wallace RB, Wassertheil-Smoller S, Whitlock E, Yano K, Adams-Campbell L, Ander- son GL, Assaf AR, Beresford SA, Black HR, Brunner RL, Brzyski RG, Ford L, Gass M, Hays J, Heber D, Heiss G, Hendrix SL, Hsia J, Hubbell FA, Jackson RD, Johnson KC, Kotchen JM, LaCroix AZ, Lane DS, Langer RD, Lasser NL, Henderson MM: Low-fat dietary pattern and risk of invasive breast cancer: the Women's Health Initiative Randomized Controlled Dietary Modification Trial.

-JAMA 2006;295:629-642.

-Prentice RL, Thomson CA, Caan B, Hubbell FA, Anderson GL, Beresford SA, Pettinger M, Lane DS, Lessin L, Yasmeen S, Singh B, Khandekar J, Shikany JM, Satterfield S, Chlebowski RT: Low-fat dietary pattern and cancer incidence in the Women's Health Initiative Dietary Modification Randomized Controlled Trial. J Natl Cancer Inst 2007;99: 1534-1543.

Rao CV, Hirose Y, Indranie C, Reddy BS: Modulation of experimental colon tumorigenesis by types and amounts of dietary fatty acids. Cancer Res 2001;61:1927-1933.

Rasmussen O, Lauszus FF, Christiansen C, Thomsen C, Hermansen K: Differential effects of saturated and monounsaturated fat on blood glucose and insulin responses in subjects with non-insulin-dependent diabetes mellitus. Am J Clin Nutr 1996;63:249-253.

Reddy BS, Meura Y: Tumor promotion by dietary fat in azoxymethane-induced colon carcinogenesis in female F344 rats: influence of amount and source of dietary fat. J Natl Cancer Inst 1984;72:745-750.

- Rohrmann S, Platz EA, Kavanaugh CJ, Thuita L, Hoffman SC, Helzlsouer KJ: Meat and dairy consumption and subsequent risk of prostate cancer in a US cohort study. Cancer Causes Control 2007; 18:41-50.

Rose DP, Haffner SM, Baillargeon J: Adiposity, the metabolic syndrome, and breast cancer in African-American and white American women. Endocr Rev 2007;28:763-777.

Rouillier P, Senesse P, Cottet V, Valléau A, Faivre J, Boutron-Ruault MC: Dietary patterns and the adenomacarcinoma sequence of colorectal cancer. Eur J Nutr 2005;44:311-318.

Saintot M, Mathieu-Daude H, Astre C, Grenier J, Simony-Lafontaine J, Gerber M: Oxidantantioxidant status in relation to survival among breast cancer patients. Int J Cancer 2002;97:574-579.

Schulz M, Hoffmann K, Weikert C, Nöthlings U, Schulze MB, Boeing H: Identification of a dietary pattern characterized by high-fat food choices associated with increased risk of breast cancer: the European Prospective Investigation into Cancer and Nutrition (EPIC)Potsdam Study. Br J Nutr 2008;1:1-5.

Shannon J, King IB, Moshofsky R, Lampe JW, Gao DL, Ray RM, Thomas DB: Erythrocyte fatty acids and breast cancer risk: a case-control study in Shanghai, China. Am J Clin Nutr 2007;85:1090-1097.

Siari S, Scali J, Richard A, Tretarre B, Daures JP, Padilla M, Grosclaude P, Gerber M: Subregional variations of dietary consumption and incidences of cancer in Southern France; in Riboli and Lambert (eds): Nutrition and Lifestyle: Opportunities for Cancer Prevention (56-3). Lyon, IARC Scientific Publications, 2002.

-Siezen CL, Bueno-de-Mesquita HB, Peeters PH, Kram NR, van Doeselaar M, van Kranen HJ: Polymorphisms in the genes involved in the arachidonic acid-pathway, fish consumption and the risk of colorectal cancer. Int J Cancer 2006;119:297-303.

Sieri S, Krogh V, Ferrari P, Berrino F, Pala V, Thiébaut ACM, Tjønneland A, Olsen A, Overvad K, Uhre Jakobsen M, ClavelChapelon F, Chajes V, Boutron-Ruault MC, Kaaks R, Linseisen J, Boeing H, Nöthlings U, Trichopoulou A, Nasak A, Lagiou P, Panico S, Palli D, Vineis P, Tumino R, Lund E, Kumle M, Skeie G, Gonzalez CA, Ardanaz E, Amiano P, Tormo MJ, Martínez-García C, Quiros JR, Berglund G, Gullberg B, Hallmans G, Lenner P, Bueno-de-Mesquita HB, van Duijnhoven FJB, Peeters PH, van Gils $\mathrm{CH}$, Key TJ, Crowe FL, Bingham S, Khaw KT, Rinaldi S, Slimani N, Jenab M, Norat T, Riboli E: Dietary fat and breast cancer risk in the European Prospective Investigation into Cancer and Nutrition. Amer J Clin Nut 2008; 88:1304-1312.

-Simonsen N, van't Veer P, Strain JJ, MartinMoreno JM, Huttunen JK, Navajas JF, et al: Adipose tissue n-3 and n-6 fatty acid content and breast cancer in the EURAMIC study. Am J Epidemiol 1998;147:342-352.

-Stoneham M, Goldacre M, Seagroatt V, Gill L: Olive oil, diet and colorectal cancer: an ecological study and a hypothesis. J Epidemiol Commun Health 2000;54:756-760.

-Stripp C, Overvad K, Christensen J, Thomsen BL, Olsen A, Møller S, Tjønneland A: Fish intake is positively associated with breast cancer incidence. J Nutr 2003;133:3664-3669.

-Strom SS, Yamamura Y, Forman MR, Pettaway CA, Barrera SL, DiGiovanni J: Saturated fat intake predicts biochemical failure after prostatectomy. Int J Cancer 2008;122:25812585.

Tang ZC, Shivapurkar N, Frost A, Alabaster O: The effect of dietary fat on the promotion of mammary and colon cancer in a dual-organ rat carcinogenesis model. Nutr Cancer 1996; 25:151-159.

Tannenbaum A: The genesis and growth of tumors. III. Effects of a high-fat diet. Cancer Res 1942;2:468-475.

Theodoratou E, McNeill G, Cetnarskyj R, Farrington SM, Tenesa A, Barnetson R, Porteous M, Dunlop M, Campbell H: Dietary fatty acids and colorectal cancer: a case-control study. Am J Epidemiol 2007;166:181-195.

- Theodoratou E, Campbell H, Tenesa A, McNeill G, Cetnarskyj R, Barnetson RA, Porteous ME, Dunlop MG, Farrington SM: Modification of the associations between lifestyle, dietary factors and colorectal cancer risk by APC variants. Carcinogenesis 2008;29:17741780. 
Thiébaut A, Clavel-Chapelon F: Consommation de graisses et cancer du sein: résultats préliminaires de la cohorte E3N-EPIC. Bull Cancer 2001;88:954-958.

-Thiébaut ACM, Kipnis V, Chang SC, Subar AF, Thompson FE, Rosenberg PS, Hollenbeck AR, Leitzmann M, Schatzkin A: Dietary fat and postmenopausal invasive breast cancer in the National Institutes of Health - AARP Diet and Health Study Cohort. J Ntl Cancer Inst 2007;99:451-462.

Thiébaut ACM, Chajès V, Gerber M, BoutronRuault MC, Joulin V, Lenoir G, Berrino F, Riboli E, Bénichou J, Clavel-Chapelon F: Dietary intakes of $\omega-6$ and $\omega-3$ polyunsaturated fatty acids and the risk of breast cancer. Int J Cancer 2009;124:924-931.

-Verhoeven DT, Assen N, Goldbohm RA, Dorant E, van't Veer P, Sturmans F, Hermus RJ, van den Brandt PA: Vitamins $\mathrm{C}$ and $\mathrm{E}$, retinol, beta-carotene and dietary fibre in relation to breast cancer risk: a prospective cohort study. Br J Cancer 1997;75:149_ 155.
Wakai K, Tamakoshi K, Date C, Fukui M, Suzuki S, Lin Y, Niwa Y, Nishio K, Yatsuya H, Kondo T, Tokudome S, Yamamoto A, Toyoshima H, Tamakoshi A; JACC Study Group: dietary intakes of fat and fatty acids and risk of breast cancer. A prospective study in Japan. Cancer Sci 2005;96:590-599.

Wakai K, Hirose K, Matsuo K, Ito H, Kuriki K, Suzuki T, Kato T, Hirai T, Kanemitsu Y, Tajima K: Dietary risk factors for colon and rectal cancers: a comparative case-control study. J Epidemiol 2006;16:125-135.

-Wang J, John EM, Horn-Ross PL, Ingles SA: Dietary fat, cooking fat and breast cancer risk in a multiethnic population. Nut Cancer 2008;60:492-504.

-Wallström P, Bjartell A, Gullberg B, Olsson H, Wirfalt E: A prospective study on dietary fat and incidence of prostate cancer (Malmö, Sweden). Cancer Causes Control 2007;18: 1107-1121.
Weijenberg MP, Lüchtenborg M, de Goeij AF, Brink M, van Muijen GN, de Bruine AP, Goldbohm RA, van den Brandt PA: Dietary fat and risk of colon and rectal cancer with aberrant MLH1 expression, APC or KRAS genes. Cancer Causes Control 2007;18:865-879.

-Wirfalt E, Vessby B, Mattisson I, Gullberg B, Olsson H, Berglund G: No relations between breast cancer risk and fatty acids of erythrocyte membranes in postmenopausal women of the Malmö Diet Cancer cohort (Sweden). Eur J Clin Nutr 2004;58:761-770.

WCFR/AICR: Food, Nutrition, and the Prevention of Cancer: A Global Perspective. Washington, American Institute for Cancer Research, 1997.

WCFR/AICR: Food Nutrition, Physical Activity and the Prevention of Cancer: A Global Perspective. Washington, American Institute for Cancer Research, 2007.

- Xu WH, Matthews CE, Xiang YB, Zheng W, Ruan ZX, Cheng JR, Gao YT, Shu XO: Effect of adiposity and fat distribution on endometrial cancer risk in Shanghai women. Am J Epidemiol 2005;161:939-947. 